

Digitized by the Internet Archive in 2012 with funding from Royal Ontario Museum

http://archive.org/details/hawksowlsofontar00snyd 





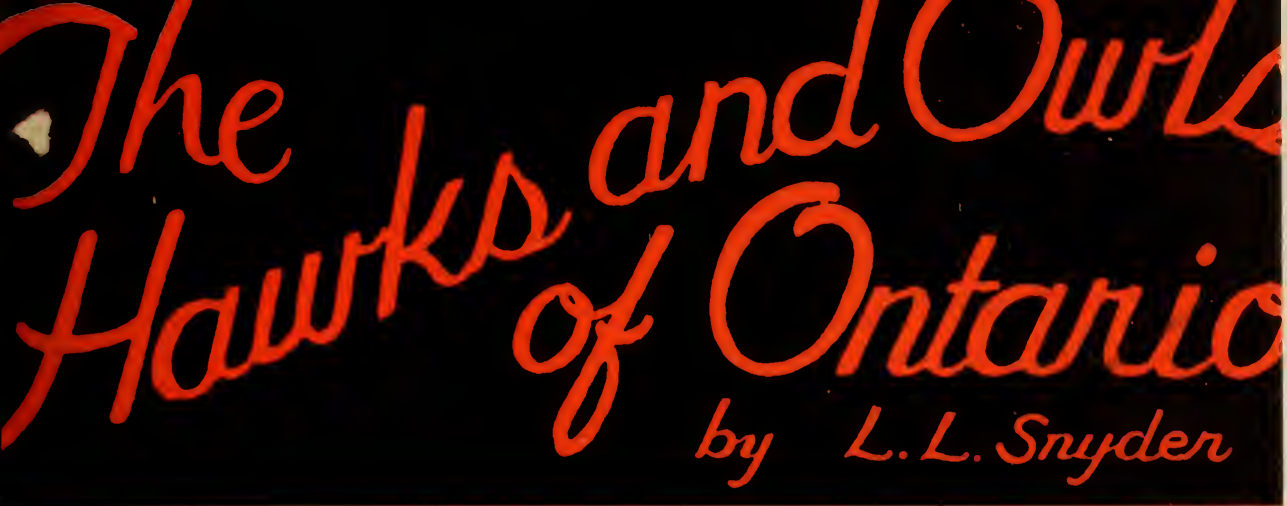



HANDBOOK NO. 2, REVISED EDITION

\section{The Hawks and Owls of Ontario}

BY

L. L. SNYDER

ILLUSTRATIONS BY T. M. SHORTT

PUBLISHED BY

Royal Ontario Museum of Zoology

1947 
Printed by

University of Toronto Press 


\section{Preface}

THIs handbook has been prepared as an introduction to the study of the hawks and owls of Ontario. Sections are devoted to some general consideration of the biology of these birds, including their place, rôle and interrelationships in nature, and to their systematic classification; a list is given of all species and subspecies that occur, or have occurred, in Ontario. Specific accounts present information relative to the distribution and numbers of each species in the province, and include such brief descriptions of plumages and behaviour as may be helpful in identifying these birds in life. Information relative to the food materials found in the examination of five hundred and eighty-two stomachs of hawks and owls taken in Ontario is presented graphically. Although this information is incomplete in certain respects it is indicative of food tendencies of most species during the period of their residence in the province. Pen-and-ink drawings of each species illustrate the text. These are the work of Mr. T. M. Shortt of the Museum's staff. Criticisms of the text and aid in food analyses, by various members of the staff, have in large measure assisted in the construction of this booklet.

L. L. S. 


\section{Contents}

INTRODUCTION . . . . . . . . . . . . . . 5

The Biology of the Birds of Prey . . . . . . 7

The Place and Rôle of the Birds of Prey in Nature. 7

Food Competition and Diet Variation . . . . 10

Physical Characteristics and the Classification of Hawks and Owls. . . . . . . . . . . 11

Hawks and Their Allies .

A List of Ontario Species and Subspecies . . 12

Owls . . . . . . . . . . . . . 14

A List of Ontario Species and Subspecies . . 14

Food Studies of Ontario Hawks and Owls . . . 15

Descriptive Accounts of Species . . . . . . 17

to 47 


\section{The Hawks and Owls of Ontario}

\section{INTRODUCTION}

$\mathrm{O}^{\mathrm{F}}$ the many branches of natural history none is more popular than the study of birds. It is perhaps natural that the colourful and conspicuous song birds should have attracted most attention, but to anyone who takes more than a superficial interest in birds, a knowledge of the characteristics and habits of other groups becomes necessary and equally fascinating. No group is more interesting to the serious student of nature than that of the hawks and owls.

Hawks and owls are flesh-eating birds living on smaller animals captured by dint of speed, power and dexterity. Their habits are in accord with physical modifications which fit them for this way of living; naturally, they are aggressive in behaviour. With such inherent endowments no other means of life or mode of behaviour is possible to them; the swooping hawk or the stealthy owl striking down lesser forms of life is doing so for food. Because of this mode of living many people find it difficult to appreciate the birds of prey; they are regarded as pirates or outlaws in nature. However, the carnivorous element is so inherently part and parcel of the arrangement of nature that we should at all times consider carefully the justice of our aversions toward it and contemplate the probable outcome of any practical attempts we may be inclined to make toward its elimination.

We are apt to misinterpret the actions of hawks and owls and also the reactions of their prey. For example, the sounds produced by animals affect us as human beings according to the kind or variety of human sentiment they appear to represent. The night call of an owl provokes in some very primitive emotions. It may suggest isolation or the dangers 
that lurk in the dark. More sanely reflected upon, it is difficult to find in the call of an owl, apart from the possible communication of the bird with others of its kind, more than a timely warning to possible victims. A mouse or small bird may conceivably be put on the alert but it is doubtful if it experiences a protracted fear. The reactions of lesser creatures must of necessity be short lived. A bird-eating hawk may dash into the midst of a group of small birds feeding on the ground or in the bushes and capture one of them; the other individuals are put to flight or cover, but shortly after the hawk has passed on they resume their feeding - they even resume their singing! There has been no long suffering of nervous shock.

Concerning this great question of the resignation of lesser animals to natural enemies, the great French naturalist Fabre* who was gifted alike with conscience, accuracy of observation and facility of expression, said: "If each creature is what it is because it is a necessary part of the plan of the supreme Artisan who has constructed the universe, why have some the right of life and death and others only the terrible duty of immolation? Do not both obey, not the gloomy law of carnage, but a kind of sovereign and exquisite sacrifice, some sort of unconscious idea of submission to a superior and collective interest?"

When the home life of the birds of prey is studied it is found that they pay the same attention to their homes as do other birds. In fact the fidelity of mated hawks to each other and to their young is known to be more firmly entrenched in their natures than is the case with many of the small song birds. From the eggs of hawks and owls tiny down-covered fledgelings are hatched which are absolutely dependent on their parents for a much longer period than in the case of most birds. The parents must bring them their natural food, guard them against their enemies, protect them from the hot sun and from rain. Food is brought regularly and offered to the helpless young with the same delicacy as would be observed in the case of song birds. Altogether the study of the home life of hawks and owls will be found as fascinating and as full of human interest as that of any other group of birds.

Regarded from the aesthetic point of view the birds of prey compel admiration. Their colouration is usually not

*LeGros, C. V. Fabre, the Poet of Science. Century Co., N.Y. 
brilliant but they exhibit delicate blendings of subdued tones, and striking patterns are frequent. The form and manner of some birds of prey have led to their use as symbols of strength and courage while others are so peculiar in their appearance as to provoke mirth. Few creatures are more striking than the golden eagle and few birds are more fascinating to observe in detail than the barn owl. It would seem that no group of birds has more dramatic appeal, or more intriguing interest bound up in their lives and forms than the birds of prey.

\section{THE BIOLOGY OF THE BIRDS OF PREY}

\section{The Place and Role of the Birds of Prey in Nature}

To understand the place which birds of prey occupy in nature one must appreciate certain of the interdependences of different forms of life. Everyone is familiar with the fact that. certain animals prey on smaller and weaker ones, but it is perhaps not so generally realized that this same principle is of universal application. The wolf eats the deer that browses on forest herbage; the lion devours the antelope that feeds on the grass of the African veldt; the fisher kills the porcupine that gnaws the bark of trees; the lynx lives on hares that feed, like the corresponding animals in the examples just cited, on vegetable matter. These are examples of food chains which are of universal occurrence in nature. But food chains frequently have more links than are shown by the examples given. For instance, the trout devours minnows which eat aquatic insects; these feed upon still smaller creatures which in turn eat microscopic plants in the water. Although this food chain is longer than the others, it resembles them in two respects - the ultimate food material is plant matter, and the animal at the upper end of the chain is a carnivore.

Hawks and owls are the carnivores of the bird world. The rough-legged hawk eats mice which live on plants; the sharp-shinned hawk kills birds and these eat insects which live on plants; the osprey catches fish which in the last analysis depend on microscopic plant life.

It will be readily appreciated that the numbers of individual animals in what may be termed the "prey group," must ordinarily be greatly in excess of the numbers in the group feeding upon them. Where there are a series of groups depending one upon the other for subsistence there is a tremen- 
dous expansion of numbers from the larger to the lesser-from top to bottom. This situation has been clearly pictured by Elton, in his very interesting and valuable book on Animal Ecology, ${ }^{*}$ in which he points out that the numerical relationships of the various interdependent groups or links in these food chains may be represented by a pyramid. Applying this idea to our birds of prey we get a picture as follows:

SHARP-SHINNED HAWK

SMALL BIRDS

INSECTS

PLANTS

From the bottom to the top of the pyramid the creatures increase in size but decrease in numbers. The rate of increase of the different species which is determined by their reproductive capacities as modified by the percentage of survival among the young is ordinarily so balanced in nature as to maintain this pyramid form of numbers.

It has been pointed out above that the birds of prey, in common with other carnivores, occupy a very definite and pre-eminent position in the scheme of nature and we are led to speculate as to the rôle which the carnivore plays in such a scheme. To understand this rôle we must remind ourselves of certain facts with reference to the numbers of living creatures. It is well known that most birds, mammals, insects and other forms of life tend to increase very rapidly in numbers. For example, mice have several young at a litter and usually several litters a year. Birds do not reproduce so rapidly, but if all the young which are hatched reached maturity and reproduced in their turn, the earth would soon be congested with birds. What actually happens under normal conditions is that the numerical abundance of birds, insects and other creatures remains moderately uniform. From a single pair of parents of a species maintaining a level of numbers, only two offspring, on the average, reach maturity and reproduce in their turn; all of the others perish. The principal factors which tend to level off populations are storms and severe weather, carnivores, parasites, disease and accidents.

*Animal Ecology by Chas. Elton. Macmillan Co., 1927. 
If it were not for the persistent action of these destructive forces each species would go on increasing until ultimately it had eaten all available food, resulting in death by starvation. Various species of insects from time to time break away from the control of natural enemies and multiply at an alarming rate. They sometimes denude trees of their leaves and devastate field crops over wide areas but ultimately a depletion of food results in their starvation, or so reduces their vitality that they perish from disease or disorders closely akin to disease. Another example of the attainment of extraordinary numbers is afforded by the varying hare of the north woods. Periodically the hares become very numerous and then some malady spreads among them and reduces their numbers almost to the vanishing point.

Throughout the ages, by a kind of trial and error process, nature has evolved a safe and steady counterforce which works against the suicidal expansion that is potential in all species. An important factor in this counterforce is the carnivore. Birds of prey, for example, are a much safer means of controlling numbers than starvation or disease because there is always the danger that these scourges may wipe out a species entirely. Carnivores do not exterminate the species on which they prey. If their prey becomes very scarce they too cease to flourish since they cannot exist in numbers disproportionate to their food. Man is the only predator at all likely to exterminate a species.

Another feature of the carnivore-prey relationship concerns the physical stamina of the prey as a result of continuous attack by natural enemies. It is evident that the birds of prey feed upon the most easily available natural food. This not only concerns the quantity of food available but the ease of capture of individuals. The individual which is least alert or is impeded by physical ills or deformities becomes the most likely prey for the carnivore. As a consequence, on the average, the carnivore eliminates the unfit and leaves the best to reproduce.

Biologically, the rôle of the bird of prey is an important one. While one's sympathies are naturally aroused by the thought or sight of smaller creatures being devoured by larger ones there is no escaping the situation that the vast majority of birds and other animals brought forth each year must be eliminated by some agency. That agency whose force is consistent with the periodic need for elimination and which 
contributes toward the maintenance of a high state of physical stamina of the prey is unquestionably the best.

With reference to this aspect of nature, the great Darwin has said: "When we reflect on this struggle, we may console ourselves with the full belief that the war of nature is not incessant, that no fear is felt, that death is generally prompt and that the vigorous, the healthy and the happy survive and multiply."

\section{Food Competition and Diet Variation}

A consideration of the food habits of the birds of prey illustrates another interesting fact of very general application in nature, namely, that creatures of the same general habit avoid direct competition in the matter of food.

Hawks illustrate this feature particularly well. The marsh hawk hunts over marshes or muskegs, the red-tailed hawk over fields and open woods, the broad-winged hawk in the evergreen forests of the north and the red-shouldered hawk in the broad-leaved forests of the south. These examples illustrate territorial and geographic segregation. A further avoidance of competition is attained by the natural selection of different items of diet. The osprey may live in the forest with the broad-winged hawk, but it feeds exclusively on fish, an item not taken by the latter; the sparrow hawk feeds in the open but it subsists to a great extent on insects, consequently it does not seriously compete with the red-tailed hawk which feeds chiefiy on larger animals.

Even in the case of two species with similar food-habits whose ranges overlap, there is a reduction of competition due to disparity of size. The Cooper's hawk and the sharp-shinned hawk are examples of this. The latter, being small, naturally feeds on smaller prey.

Direct competition is further avoided between hawks and owls since the former hunt by day and the latter largely at dusk or at night.

Although there are rather fixed limits to the list of items normally taken by most species, the range of acceptable food is sufficiently wide to assure each species a supply. Generally speaking a hawk or an owl feeds, at any given time or place, on the lesser forms of life which are most plentiful and consequently most easily procured. During migration these birds find themselves under conditions quite different from those 
of their nesting grounds. The goshawk, for example, may feed chiefly on grouse and hares while in the north woods, but when it moves southwards where these species are scarce or absent it naturally turns to the available food which is most nearly like them, such as poultry and pigeons. The sharp-shinned hawk which feeds largely on native warblers and sparrows in summer, quite naturally includes in its diet the imported English sparrow when it migrates through settled sections of the province where this sparrow is plentiful. This change of food habits is largely a matter of varying the proportions of acceptable items of diet under force of circumstances. Conversely, no species on which carnivorous birds prey is subject to a continuous attack unless its numerical status permits of it. Consequently an immunity from attack results in the upward tilt of that ever-wavering "balance of nature" which is never balanced.

\section{PHYSICAL CHARACTERISTICS \\ AND THE CLASSIFICATION \\ OF HAWKS AND OWLS}

Our modern system of classification attempts to arrange animals in an orderly series which reflects relationships and degree of development. All related groups cannot be satisfactorily joined together in a straight linear arrangement such as is mechanically enforced on us in the pages of a book since gaps are present through the extinction of many animals and also because, in nature, there was no such thing as a continuous chain of links in sequence and without branches. Classification, however, attempts to join the various groups in such a way as to result in as few breaks as possible.

Although hawks and owls exhibit certain anatomical similarities their differences are sufficiently great to require that they be placed in separate orders. In the case of the owls their affinities with the nightjars are sufficiently pronounced as to be best expressed by associating these groups rather closely together in a linear arrangement. This arrangement leaves several orders intervening between the diurnal and nocturnal birds of prey. Popularly they are associated together because of similar modifications of their beaks and 
talons but these similarities are perhaps more properly considered as examples of convergent evolution.

\section{Hawks and Their Allies}

Hawks and their allies (order Falconiformes) form a fairly natural assemblage of flesh-eating birds which are mostly active by day. Their interrelationships are largely reflected in anatomical features which are not of a superficial character, but similarities are readily observed in their exterior form. As distinct from the owls, their feathers are rather firm and closely knit, giving the plumage a more compact appearance: Their power of sight is highly developed. The eyes are directed laterally and are more or less shielded above by a protecting brow. This feature produces the well-known, keen, "hawk-eyed" expression. The usual position of their toes is three directed forward, and one backward. The eggs of hawks are as a rule pale in colour, sometimes sparsely or closely marked with reddish-brown.

No order of birds exhibits as wide a diversity and as great a development of the various types of flight as do the hawks and hawk-allies. From the long-sustained soaring of the turkey vulture-which may be watched from horizon to horizon without a noticeable wing-beat-to the bullet-like swoop of the duck hawk-which demonstrates the greatest speed developed by any bird in a limited distance-these birds are pre-eminent masters of flight. The physical organization of hawks led the early naturalists to place them at the head of the avian class, a position which is now conceded to the song birds. Hawks undoubtedly exhibit a state of mechanical perfection unequalled so far as their mode of living is concerned.

\section{$A$ List of Ontario Species and Subspecies}

\section{ORDER FALCONIFORMES}

Suborder Cathartae

FAMILY CATHARTIDAE-Large, carrion-eating birds of the New World with nearly naked heads; nostrils without a separating interior partition; wings long; hind toes attached slightly above the level of the fore toes; claws not strongly hooked.

1. Turkey Vulture, Cathartes aura 
SuPERFAMILy Falconoidea

FAMILY ACCIPITRIDAE-Small to large birds of prey, the majority with fully feathered heads; nostrils with a separating interior partition and agreeing in other characteristics of the skull; hind toes attached on a level with the fore toes; claws strongly hooked.

2. Swallow-TAIlEd Kite, Elanoides forficatus.

3. Goshawk, Accipiter gentilis.

Subspecies, for ficatus

4. Shar P-Shinned Hawk, Accipiter striatus

5. CoOper's Hawk, Accipiter cooperii

Subspecies, atricapillus

6. Red-TAILEd Hawk, Buteo jamaicensis

7. Red-Shouldered Hawk, Buteolineatus

8. BROAd-Winged Hawk, Buteo platypterus

Subspecies, velox

9. SwaInson's Hawk, Buteo swainsoni

Subspecies, borealis calurus* krideri†

10. Rough-legged Hawk, Buteo lagopus

11. Golden Eagle, Aquila chrysaetos

12. BALd EAgLe, Haliaeetus leucocephalus

13. Marsh Hawr, Circus cyaneus

Subspecies, lineatus

Subspecies, platypterus

Subspecies, s.johannis

Subspecies, canadensis

Subspecies, washingtoniensis

Subspecies, hudsonius

FAMILY PANDIONIDAE-Large, long-winged, fish-eating birds; plumage oily, with a characteristic odour; tarsi reticulate; soles of the feet with horny spikes; outer toes versatile; claws large, circular, ungrooved beneath and of uniform length.

14. Osprey, Pandion haliaetus

Subspecies, carolinensis

FAMILY FALCONIDAE-Small to medium-sized birds of prey agreeing particularly in anatomical features of the skull, which distinguish them from other hawks and hawk-like birds. The family cannot be defined by superficial characteristics.

15. Caracara, Polyborus cheriway $\ddagger$

16. Gyrfalcon, Falco rusticolus

17. Peregrine Falcon, Falco peregrinus

18. Pigeon Hawk, Falco columbarius

19. Sparrow HaWk, Falco sparverius

Subspecies, probably audubonii

Subspecies, obsoletus

Subspecies, anatum

Subspecies, columbarius $\S$

Subspecies, sparverius

* Five existing Ontario specimens are referable to this form which has been recorded from the province by Saunders, Auk, 5: 205 and Samuel, Auk, 17:386.

†A specimen compared with the type and identifiable as this form has been recorded by Fleming, Auk, 30:227.

$\ddagger$ Recorded by Brown, Auk, 10: 364, on the basis of a specimen taken near Port Arthur. Specimen now lost.

$\S$ The record of $F$. c. richardsonii, by Chamberlain, Cat. Can. Birds, 1887, p. 60 , is here rejected. 
The owls (order Strigiformes) form a remarkably homogeneous group of carnivorous birds which are chiefly active at night or at dusk. Although they resemble hawks in certain superficial characters, a careful comparison shows them to be markedly dissimilar to that group even in many of their external characters. Their plumage is as a whole soft and fluffy and their large eyes are directed forward. The set of the eyes, together with a disc of flat feathers surrounding them, give to these birds the "owl-faced" appearance which is familiar to everyone. Their sense of hearing is highly developed. The outer toes are reversible, making it natural for two to be directed forward and two backward. The eggs of owls are invariably white and spheroidal in shape.

The most remarkable characteristic of owls in general is their ability to hunt their prey at dusk or at night. Since they subsist entirely on living prey which as a rule must be closely approached before it is detected, a noiseless flight is essential. The softness of their feathers, particularly those of the wings, effectually prevents sound and makes possible a stealthy, ghost-like flight.

\section{A List of Ontario Species and Subspecies}

\section{ORDER STRIGIFORMES}

FAMILY TYTONIDAE-Medium-sized nocturnal birds of prey with relatively small eyes; facial disc heart-shaped; edge of middle claw incised into squarish teeth.

1. BARN OwL, Tyto alba

Subspecies, pratincola

FAMILY STRIGIDAE-Variously sized nocturnal birds of prey with relatively large eyes; facial disc rounded; no toothed claws; a curious asymmetry of the bony structure in the external ears in several representatives.

2. SCREECH OwL, Otus asio

3. HORNED OWL, Bubo virginianus

Subspecies, naevius*

Subspecies, virginianus $†$ wapacuthu

heterocnemis

4. Snowy OwL, Nyctea scandiaca

*The race $O . a$. aikeni is to be expected sparingly in western Ontario, Snyder, Trans. Roy. Can. Inst. 22: 190.

$\dagger$ Bubo virginianus occidentalis, the Montana Horned Owl, is recognized by the 1931 edition of the A.O.U. Check List, as occupying the region of Minnesota westward. Specimens referable to this race should be found in adjacent parts of Ontario (Rainy River, etc.). 
5. Hawk OWL, Surnia ulula

6. BARRED OWL, Strix varia

Subspecies, caparoch

Subspecies, varia

7. Great Gray Owl, Strix nebulosa

Subspecies, nebulosa

8. Long-eared Owl, Asio otus

9. Short-eared Owl, Asio flammeus

Subspecies, wilsonianus

Subspecies, flammeus

10. Texgmalm's Owl, Aegolius funereus

Subspecies, richardsoni

11. SAW-Whet OWL, Aegolius acadicus

Subspecies, acadicus

\section{FOOD STUDIES OF ONTARIO HAWKS AND OWLS}

The food graphs presented in this booklet are based on records of stomach content analyses in the Royal Ontario Museum of Zoology. The percentages of the various food items identified in each individual stomāch were carefully estimated by bulk during the examination. In combining the results of all examinations for each species, an arbitrary grouping of food materials was made which will aid the reader in forming an opinion as to whether the food habits of a particular kind of hawk or owl conflicts with man's interests. For example, the remains of wild birds identified in stomach contents have been classified into two groups, those protected by law in Ontario and those not legally protected. Poultry constitutes still another category of birds eaten. Although we can be sure that birds of prey make no food choice on the basis of man's laws, these laws indicate man's interests.

If we assume that man's interests are paramount - that we have the prerogative to condemn or acquit other creatures that live according to natural law, and that there are no extenuations even though the predator is virtually "baited" to the farm yard by unprotected poultry-there is still great difficulty in establishing a full and fair economic valuation on a hawk or an owl. For example, it is an established fact, and well known, that meadow mice girdle and destroy young orchard trees and that deer mice consume and foul cereal grains. This booklet, and many other similar studies, establishes the fact that several species of owls and certain hawks destroy these mice regularly and in quantity. If we search no further for facts we can regard these birds of prey as strictly beneficial. But if our economic accounting is more complete 
and thorough we will find that the food animals-mice-are assets in some respects. Mice are important staple foods of valuable fur-bearing animals, and they destroy weed seeds and noxious insects. Of course, we must decide what is a weed and what is a noxious insect! Thus, the book-keeping of economic evaluation becomes more and more complex. For the most part, a study of the food habits of a certain bird can produce quantitative information, but precise and complete economic evaluation is impossible. If we must judge rather than measure, then the writer suggests that we can more adequately judge as to the desirability or undesirability of an individual bird at a given time and place than we can for a species throughout the year and over its whole range.

It should not be overlooked that there are real values in wildlife which are not economic and which cannot be measured quantitatively. Most people would admit that the familiar robin has a value but if evaluation is based on its food habits alone, it cannot be graded high. Robins raid the cherry orchard; they consume earthworms in quantity-these creatures are important in mixing and fertilizing the soil and in making it pervious to air and water. Do we not value the robin most for its song, for its moderate and flattering familjarity, for its very being? How can these things be given economic and quantitative values? How many songs equal a quart of cherries? What is the dollars-and-cents value of the sight of a soaring eagle, or the wise look of an owl?

Some additions have been made to the food studies of hawks and owls in this revised reprint. As in the first edition, information is still lacking or inadequate relative to certain species.

It is a sad commentary to make, but shortly after the appearance of the original edition of this booklet, which was intended to aid in a better understanding of carnivorous birds, all protection was removed from all hawks and owls in the Province of Ontario. This was definitely a retrograde step. The only correction made subsequently is that protection has been restored to "ospreys and eagles." Ontario laws now exclude from protection, hawks ("which word shall not be interpreted to include ospreys and eagles"), owls, crows, cowbirds, blackbirds (grackles), starlings and house sparrows. Although the common feral pigeon is not mentioned and thus might appear to be protected, it is not legally regarded as a "wild bird." 
Descriptive Accounts of Species 


\section{TURKEY VULTURE}

Length* -approx. 30 inches

Spread* ${ }^{*}$ approx. 70 inches

This is the only vulture which occurs in Ontario. It is essentially a bird of more southern regions but it appears

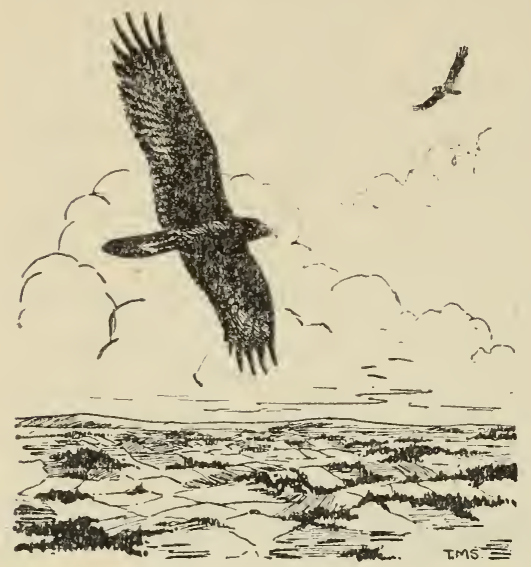
fairly regularly in southern Ontario north to Georgian Bay, and in Rainy River and southwestern Kenora Districts of western Ontario. However, it is not common in this, the northern part of its range. Its plumage is nearly black and the bare skin of the head is red. In flight the borders of the wings beneath the flight feathers appear grey when the bird is within moderate range. The bill is white, forming a conspicuous field mark even at a distance at which the characteristically naked head cannot be perceived. The marvellous soaring flight of this bird is observed at its best on sunny or windy days. A vulture may be in sight for an hour or more without a single wingbeat being noted by the observer. The species is also known as the "Turkey Buzzard."

THE FOOD OF THIS SPECIES IS ENTIRELY CARRION AS SHOWN BY STUDIES

MADE ELSEWHERE

No stomachs examined.

*The measurements given in the following accounts are the average for the two sexes and were taken as follows: length, from tip of bill to end of longest tail feather: spread, from tip to tip of outstretched wings. 


\section{SWALLOW-TAILED KITE}

Length-approx. 24 inches

Spread-approx. 47 inches

This hawk is a tropical and subtropical species which has occurred so rarely in northern latitudes as to render the chance

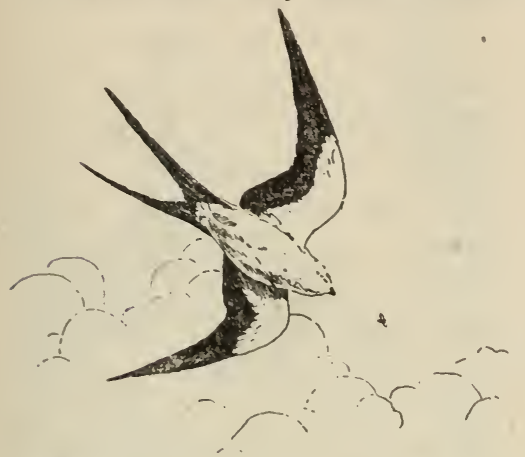

of observing it in Ontario highly improbable. It has been noted in the province but such occurrences can only be considered as accidental. The curious long, forked tail of this hawk gives a rather false impression of its size. However, a casual observer would readily identify the bird because of the shape of

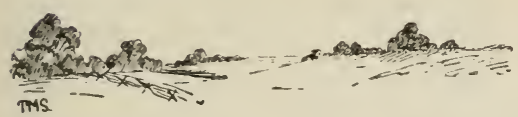
the tail, together with the contrasting black and white colour pattern. In flight it is said to be extraordinarily graceful. It spends most of its time on the wing, and due to its form and flight, it is said to resemble a gigantic swallow.

THE FOOD OF THIS SPECIES IS COMPOSED OF SNAKES, FROGS AND LARGE INSECTS ACCORDING TO STUDIES MADE ELSEWHERE

No stomachs examined. 


\section{GOSHAWK}

Length-approx. 22 inches

Spread-approx. 44 inches

The goshawk is rare in Ontario except in the autumn of certain years when it migrates southward. If it becomes
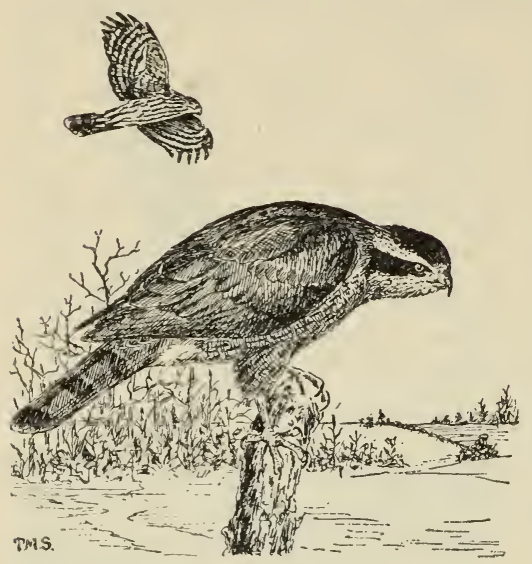
conspicuous at such times it is partially due to its boldness. The goshawk may be distinguished from most other hawks of similar size by its long tail and rounded wings which are regularly barred below. Adults appear rather uniformly blue-grey at a distance but at close range it may be observed that they are finely barred below and that areas through the eyes and on the top of the head are slaty black. Immatures are brown above and buffy white below, streaked with brown. They are frequently indistinguishable from immatures of Cooper's hawk in the field. The flight of the goshawk is swift and usually direct but at times it is wavering. The species frequently ventures about open cultivated land and even about cities during its migrations.

ORIGIN OF 15 STOMACHS

EXAMINED OF WHICH 9 WERE EMPTY

\begin{tabular}{|c|c|c|}
\hline Locality & Mth. & No. \\
\hline $\begin{array}{l}\text { King Tp., York Co......... } 4 \\
\text { Lobo Tp., Middlesex Co... } 2 \\
\text { Pt. Sydney, Muskoka Dist.. } \\
\text { Ravenshoe, York Co........ } 1 \\
\text { Toronto, York Co......... } \\
\text { Wiarton, Bruce Co........ } \\
\text { "Ontario", .............. } 1\end{array}$ & $\begin{array}{l}\text { Jan. } \\
\text { Feb. } \\
\text { Mar. } \\
\text { Apr. } \\
\text { May } \\
\text { June } \\
\text { July } \\
\text { Aug. } \\
\text { Sept. } \\
\text { Oct. } \\
\text { Nov. } \\
\text { Dec. }\end{array}$ & $\begin{array}{l}0 \\
1 \\
0 \\
0 \\
0 \\
0 \\
0 \\
0 \\
1 \\
5 \\
8 \\
0\end{array}$ \\
\hline
\end{tabular}

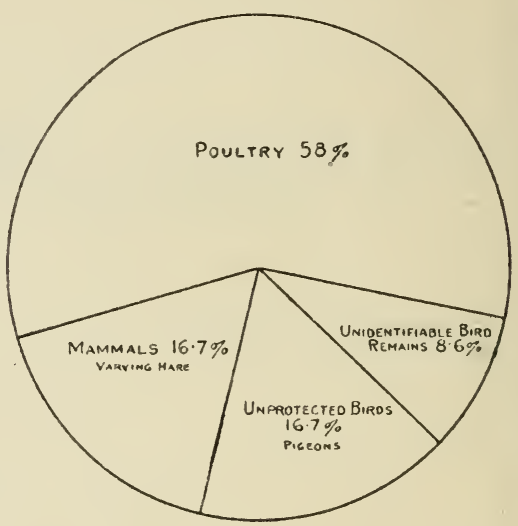

The above graph is largely based on the results of the examination of specimens taken in the fall in settled sections of the province. The high percentage of poultry taken by the goshawk shows the necessity of guarding against it during its occasional visits to cultivated areas in the south. 


\section{SHARP-SHINNED HAWK}

Length-approx. 12 inches Spread-approx. 23 inches

This little hawk is a rather scarce summer resident of wooded parts of Ontario, occurring more regularly in the

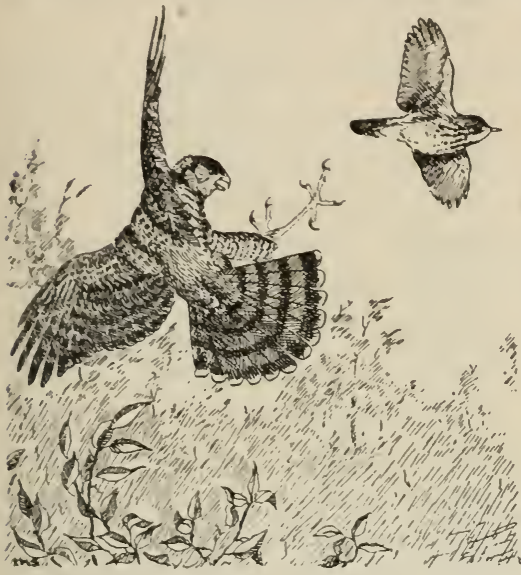

north. In the autumn it migrates southward, concentrating in large numbers in extreme southern Ontario, probably from vast areas of Ontario and Quebec. Adults are dark slaty grey above and cross-barred below with whitish and reddish brown. Immatures are dark brown above and whitish below, streaked with brown. The small size and relatively long tail which is nearly square at the end aid in identifying this hawk in the field. In summer it is usually found in thick woods where its flight, usually at low elevations, consists of a series of rapid wingbeats alternated with sailing. Its progress is rapid and shifting as it sweeps in and out among the trees and bushes. On migrations it usually frequents wooded sections but occasionally it ventures into open territory where its flight is more direct.

\begin{tabular}{|c|c|c|}
\hline Locality & Mth. & No. \\
\hline 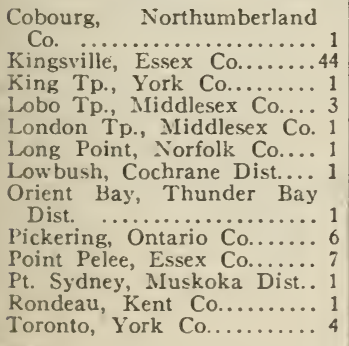 & $\begin{array}{l}\text { Jan. } \\
\text { Feb. } \\
\text { Mar. } \\
\text { Apr. } \\
\text { May } \\
\text { June } \\
\text { July } \\
\text { Aug. } \\
\text { Sept. } \\
\text { Oct. } \\
\text { Nov. } \\
\text { Dec. }\end{array}$ & $\begin{array}{r}1 \\
0 \\
0 \\
0 \\
2 \\
1 \\
7 \\
2 \\
51 \\
5 \\
2 \\
1\end{array}$ \\
\hline
\end{tabular}

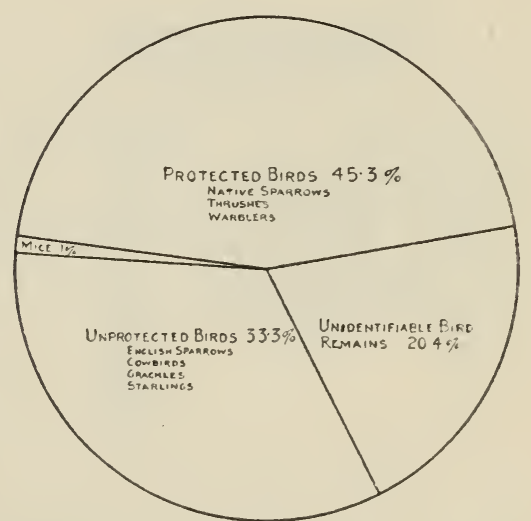

This graph is indicative of the food of the sharp-shinned hawk throughout the province and for the complete seasons of its residence here. This is unquestionaly a bird-eating species, consuming both protected and unprotected small birds according to the supply. 


\section{COOPER'S HAWK}

Length-approx. 17 inches

Spread-approx. 30 inches

Cooper's hawk is a rather scarce inhabitant of southern Ontario in summer, ranging northward only to the fringe of

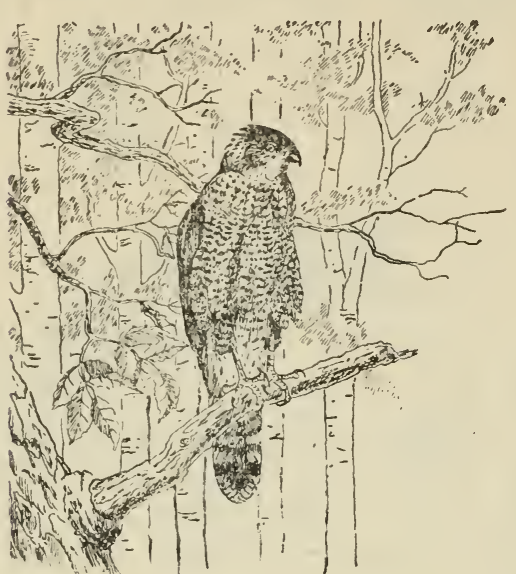
the vast evergreen forests of the north. During the autumn migration when this species concentrates in the extreme southern part of the province it appears to be fairly numerous. Cooper's hawk is like a large edition of the sharpshinned hawk, adults and immatures resembling corresponding ages of that species. This species, however, has a perceptibly rounded tail which, together with its large size, aids in distinguishing it. Large immature females seldom can be differentiated from immature males of the goshawk in the field. The flight of Cooper's hawk is swift. While hunting it sweeps about among the trees, usually not far from the ground, directing its course this way and that, apparently according to the possibilities of the cover. Its flight in the open, where it frequently ventures, is more direct and is characterized by alternate flapping and sailing.

\begin{tabular}{|c|c|c|}
\hline Locality & Mth. & No. \\
\hline $\begin{array}{l}\text { Bowmanville, Durham Co.. } 1 \\
\text { King Tp., York Co......... } 1 \\
\text { Kingsville, Essex Co.......14 } \\
\text { Lobo Tp., Middlesex Co.... } 1 \\
\text { Off Lake, Rainy River Dist. } 1 \\
\text { Pt. Sydney, Muskoka Dist.. } 1 \\
\text { Rainy River, Rainy River } \\
\text { Dist. …................... } 1\end{array}$ & $\begin{array}{l}\text { Jan. } \\
\text { Feb. } \\
\text { Mar. } \\
\text { Apr. } \\
\text { May } \\
\text { June } \\
\text { July } \\
\text { Aug. } \\
\text { Sept. } \\
\text { Oct. } \\
\text { Nov. } \\
\text { Dec. }\end{array}$ & $\begin{array}{l}0 \\
1 \\
2 \\
1 \\
1 \\
0 \\
1 \\
1 \\
4 \\
6 \\
2 \\
1\end{array}$ \\
\hline
\end{tabular}

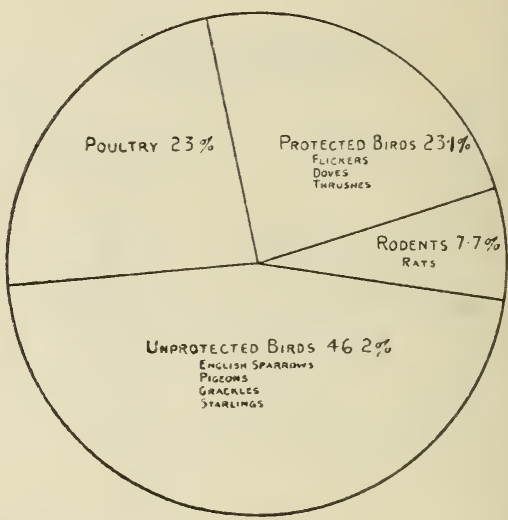

The above graph is based on the examination of specimens from various parts of the range of Cooper's hawk in Ontar!o, and from most of the months of the year and therefore probably represents the average food habits of this species. Birds, including poultry, are its chief food, the latter being a more notable item in the fall during migration. 


\section{RED-TAILED HAWK}

This large picturesque hawk is becoming very scarce in Ontario. Although it ranges well northward it is more to be

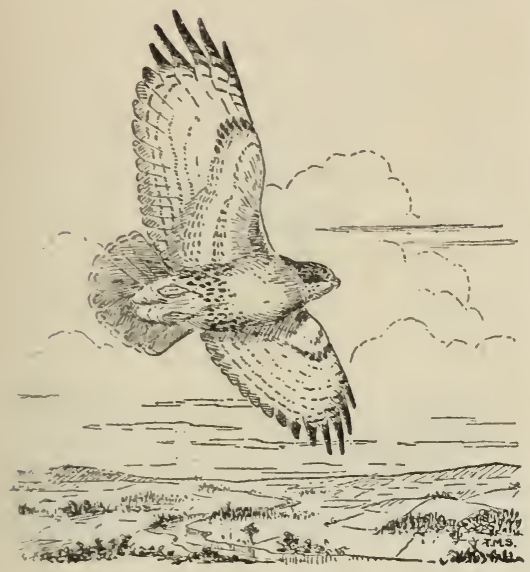

expected in southern Ontario. Here, the reduction of wooded areas has created conditions adverse to it. Typical adults have bright, reddish-brown tails and a sparse belt of dark spots across the lower part of the white under parts. Immatures have the tails barred with dark- and light-greybrown and the belt on their white underparts is more conspicuous. The soaring flight of the red-tail on sunny and windy days may carry it over open country and woodland alike. Seen on the wing the relative shortness and broadness of the tail is noticeable as is also the rounded shape of the wings. The cry, a long-drawn, hissing whistle, is often heard from adults in summer. Redtails rarely winter in the province. They migrate southward in circling and soaring bands.

\section{ORIGIN OF 28 STOMACHS \\ EXAMINED OF WHICH 6 WERE EMPTY}

\begin{tabular}{|c|c|c|}
\hline Locality & Mth. & No. \\
\hline 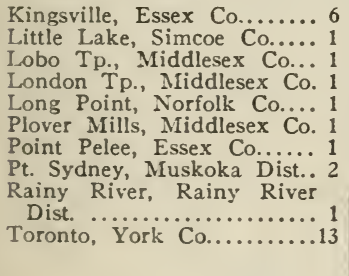 & $\begin{array}{l}\text { Jan. } \\
\text { Feb. } \\
\text { Mar. } \\
\text { Apr. } \\
\text { May } \\
\text { June } \\
\text { July } \\
\text { Aug. } \\
\text { Sept. } \\
\text { Oct. } \\
\text { Nov. } \\
\text { Dec. }\end{array}$ & $\begin{array}{l}1 \\
3 \\
0 \\
1 \\
2 \\
0 \\
1 \\
0 \\
1 \\
9 \\
8 \\
2\end{array}$ \\
\hline
\end{tabular}

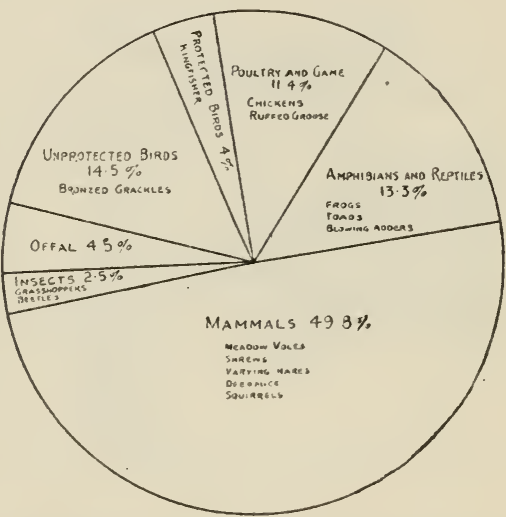

The notable feature of the diet of the red-tailed hawk, as shown by the above graph is its variety. Although the specimens examined in this study were from cultivated sections of the province and were not as numerous as might have been desired, the results suggest that the species seldom interferes with man's interests. 


\section{RED-SHOULDERED HAWK}

Length-approx. 21 inches

Spread-approx. 40 inches

Like the red-tail, this hawk is becoming scarce in the province, although it may be somewhat more numerous than

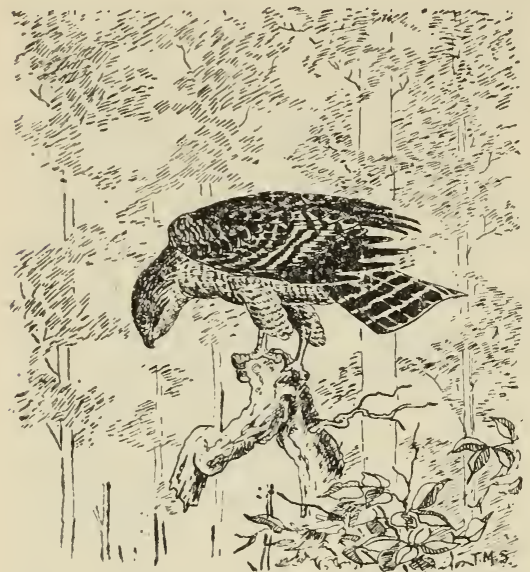

that species. It frequents old woods of a type which is remnant in southern Ontario. Northward, beyond cultivated sections, it occurs rarely. Adults are colourfully marked below with closely arranged cross-bars of tawny reddish brown and white. Above, they are largely dark brown. The chestnut "shoulders" are rarely visible at a distance. Their tails are strongly barred with broad dark, and narrow white bands. Immatures especially, resemble the broad-winged hawk, but the summer ranges of the two scarcely overlap. They are more generally streaked below than young red-tails. This hawk frequently soars; its flapping flight, usually under forest cover, is somewhat sluggish and not protracted. Its call is a prolonged. squealing "keeoooo." A few individuals occasionally winter in southern Ontario.

ORIGIN OF 12 STOMACHS EXAMINED OF WHICH 2 WERE EMPTY

\begin{tabular}{|c|c|c|}
\hline Locality & & No. \\
\hline $\begin{array}{l}\text { Columbus, Ontario Co..... } 1 \\
\text { Concord, York Co......... } 1 \\
\text { Lobo Tp., Middlesex Co... } 1 \\
\text { London Tp., Middlesex Co. } 3 \\
\text { Plover Mills, Middlesex Co. } 1 \\
\text { Port Hope, Durham Co..... } 1 \\
\text { Toronto, York Co......... } 3 \\
\text { Windsor, Essex Co........ } 1\end{array}$ & $\begin{array}{l}\text { Jan. } \\
\text { Feb. } \\
\text { Mar. } \\
\text { Apr. } \\
\text { May } \\
\text { June } \\
\text { July } \\
\text { Aug. } \\
\text { Sept. } \\
\text { Oct. } \\
\text { Nov. } \\
\text { Dec. }\end{array}$ & $\begin{array}{l}0 \\
0 \\
1 \\
4 \\
1 \\
3 \\
0 \\
0 \\
0 \\
1 \\
1 \\
1\end{array}$ \\
\hline
\end{tabular}

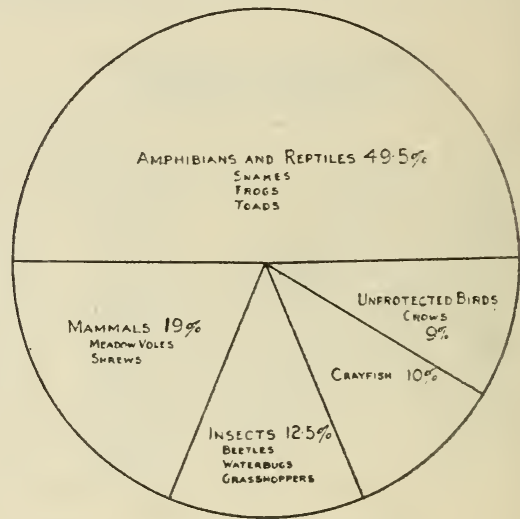

The food of the red-shouldered hawk as suggested by the above graph would present a difficult problem if a purely economic valuation were attempted. The various items eaten by this species include animals ordinarily considered destructive to man's crops and stores as well as some which are economic allies: still others may be considered neutral since they affect man very indirectly. 


\section{BROAD-WINGED HAWK}

This species is fairly common in the north woods in summer. It rarely occurs in cultivated sections of the pro-
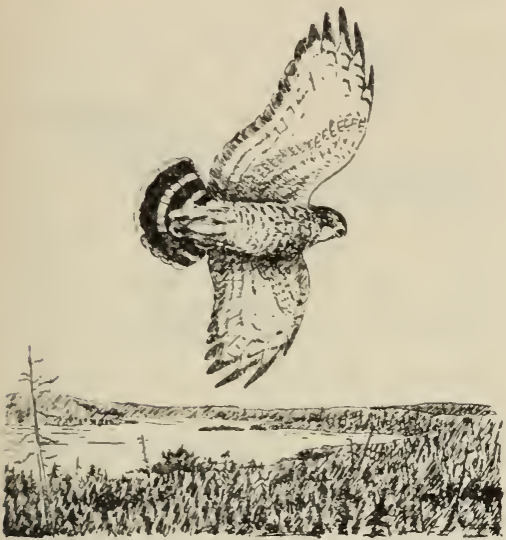
vince except on migration. Adults are dark brown above; below they are rather coarsely cross-barred with brown or reddish-brown and white. Immatures are similar to adults above but below they are streaked rather generally with heavy, brown markings similar to those of the red-shouldered hawk. The broadwinged hawk may be observed soaring above the forest or flying low through the forest or about clearings. Its call is a prolonged, whistled "kiteeee," high in pitch and somewhat hissing in quality. The species migrates in groups which are sufficiently compact in the fall to be termed flocks. The circling and soaring of the individuals within the flock forms a maze within the more direct course of the flock as a whole.

ORIGIN OF 23 STOMACHS EXAMINED OF WHICH 4 WERE EMPTY

\begin{tabular}{|c|c|c|}
\hline Locality & Mth. & No. \\
\hline $\begin{array}{l}\text { Guelph, Wellington Co..... } 1 \\
\text { Havelock, Peterborough Co. } 1 \\
\text { Kingsville, Essex Co....... } 3 \\
\text { Lobo Tp., Middlesex Co... } 2 \\
\text { London Tp., Middlesex Co. } 2 \\
\text { Lowbush, Cochrane Dist.... } 1 \\
\text { Macdiarnid, Thunder Bay } \\
\text { Dist. ................. } 2 \\
\text { Pickering, Ontario Co..... } 1 \\
\text { Point Pelee, Essex Co.... } 1 \\
\text { Pt. Sydney, Muskoka Dist.. } 7 \\
\text { Strathroy, Middlesex Co... } 1 \\
\text { Toronto, York Co......... } 1\end{array}$ & $\begin{array}{l}\text { Jan. } \\
\text { Feb. } \\
\text { Mar. } \\
\text { Apr. } \\
\text { Nay } \\
\text { June } \\
\text { July } \\
\text { Aug. } \\
\text { Sept. } \\
\text { Oct. } \\
\text { Nor. } \\
\text { Dec. } \\
\text { No date }\end{array}$ & $\begin{array}{l}0 \\
0 \\
0 \\
3 \\
4 \\
2 \\
4 \\
2 \\
7 \\
0 \\
0 \\
0 \\
1\end{array}$ \\
\hline
\end{tabular}

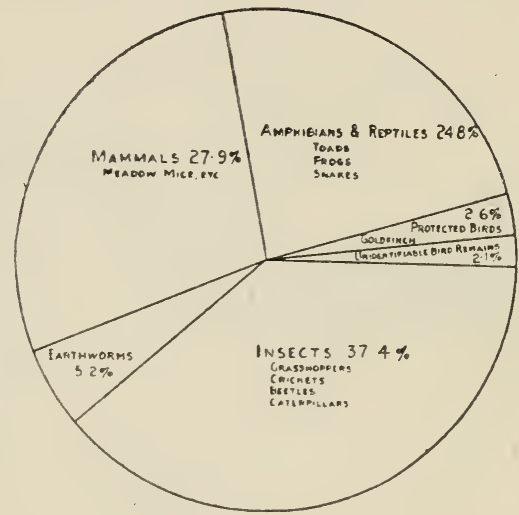

The above graph, which is based on the examination of specimens taken from many sections and during most of the time the species is a resident of the province, presents a fairly accurate picture of the proportions and items of diet of the broad-winged hawk. Even those specimens taken on migration through cultivated sections of Ontario were found not to interfere with man's economic interests. 


\section{SWAINSON'S HAWK}

Length-approx. 20 inches

Spread-approx. 48 inches

This hawk is only of accidental occurrence in Ontario and its appearance has been mostly noted during fall migration

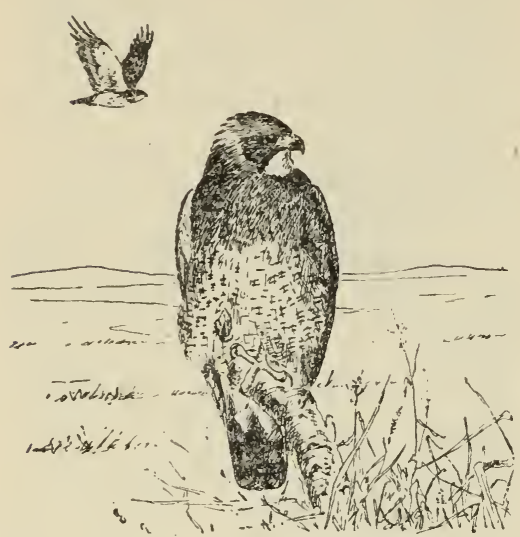
periods. There are at least two distinct colour phases of the adult stage of Swainson's hawk, viz.: a light and a dark phase, but numerous intermediates occur. Immatures form a rather distinct buffy type. In size and habits the species is similar to our other soaring hawks, more particularly the red-tailed hawk. In all but the black phase it would be distinguishable from the others by the clustering of brownish markings or the even dark tone across the upper breast. The dark phase resembles a dark rough-legged hawk, but is smaller. However, the buffy immature plumage is most apt to be observed in birds occurring in Ontario. The species is normally a prairie bird and its status in Ontario has probably never been very different from what it is today.

THE FOOD OF THIS SPECIES IS LARGELY MADE UP OF SMALL MAMMALS AND LARGE INSECTS ACCORDING TO STUDIES MADE ELSEWHERE

No stomachs examined. 


\section{ROUGH-LEGGED HAWK}

Length-approx. 22 inches $\quad$ Spread-approx. 52 inches

This Arctic hawk is a regular fall migrant in Ontario and sometimes it occurs as a fairly plentiful winter resident of
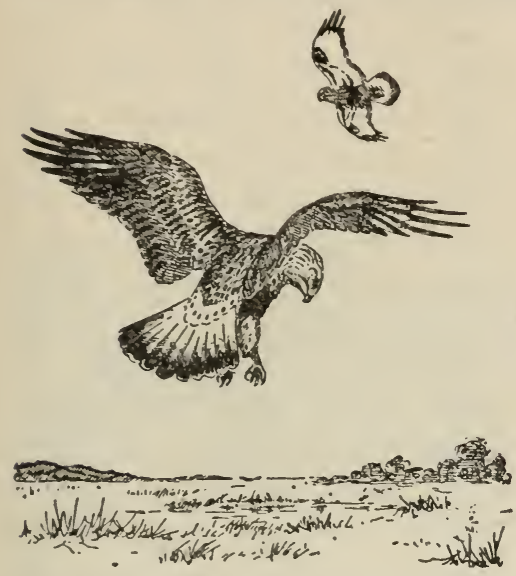

southern sections. It is rarely observed in spring and is not known to nest in the province. Two distinct colour phases are exhibited, viz.: a dark and a light phase, but some individuals show intermediate plumages. The large size of the rough-leg, together with a considerable amount of black below, the white base of the tail and the pronounced black spots at the wrist of the underwing, aid in distinguishing the lighter phases from other hawks in the field. The dark phase is almost completely sooty black. The legs are feathered to the base of the toes. On migration the rough-leg frequents marshes. In hunting it flies low, at times hovering over promising spots. Rough-legs migrate in fall in scattered bands, or individually, sometimes soaring and sometimes with direct flight.

\section{ORIGIN OF 58 STOMACHS EXAMINED OF WHICH 6 WERE EMPTY}

\begin{tabular}{|c|c|c|}
\hline Locality & Mth. & No. \\
\hline 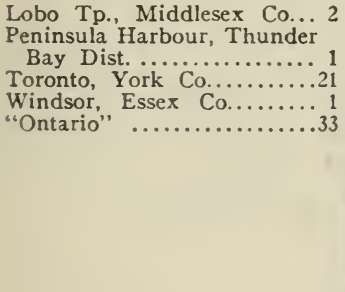 & $\begin{array}{l}\text { Jan. } \\
\text { Feb. } \\
\text { Mar. } \\
\text { Apr. } \\
\text { May } \\
\text { June } \\
\text { July } \\
\text { Aug. } \\
\text { Sept. } \\
\text { Oct. } \\
\text { Nov. } \\
\text { Dec. } \\
\text { "Fall" }\end{array}$ & $\begin{array}{r}0 \\
0 \\
0 \\
0 \\
0 \\
0 \\
0 \\
0 \\
0 \\
5 \\
21 \\
0 \\
32\end{array}$ \\
\hline
\end{tabular}

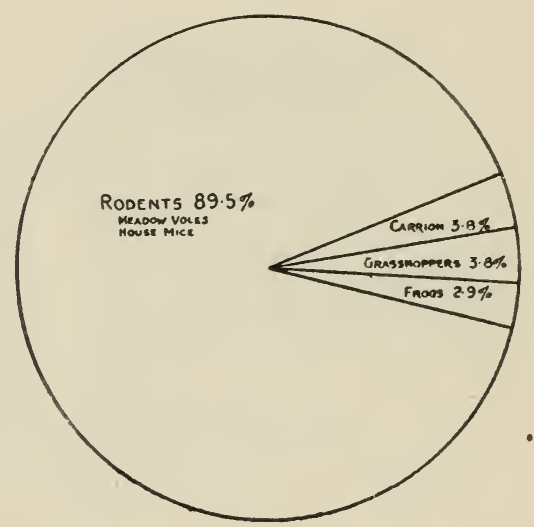

The above graph shows that the rough-legged hawk is an inveterate mouser during its fall migrations through Ontario. Few hawks have as unvaried a diet as this species and according to the examinations on which the graph is based it does not interfere with man's interests. 


\section{GOLDEN EAGLE}

Except as a straggling wanderer during fall and winter, the golden eagle is rare in Ontario. There are a few reports of it nesting in the province which appear to be valid. The species is largely confined to the

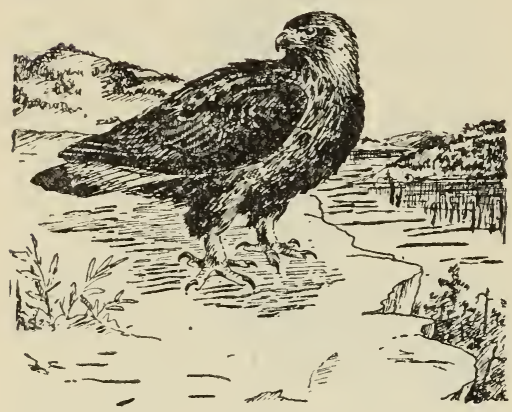
mountain country of western North America and the far north. Few of the birds seen in Ontario are fully adult. On the wing they would appear completely dark brown, almost black, but at closer range the feathers of the hindneck are seen to be golden brown. A basal area of light mottled markings is concealed by the tail coverts. Immatures show the basal half of the tail white and a perceptible light area beneath the wrists of the wings. The most certain character for distinguishing this species from the bald eagle at any age is the possession of completely feathered legs. In the golden eagle light brown feathers cover the whole of the legs, to the base of the toes.

ORIGIN OF 6 STOMACHS EXAMINED OF WHICH 2 WERE EMPTY

\begin{tabular}{|c|c|c|}
\hline Locality & Mth. & No. \\
\hline $\begin{array}{l}\text { Grassy Narrows, Kenora } \\
\text { Dist. .................. } 1 \\
\text { Loon, Thunder Bay Dist... } 2 \\
\text { Redditt, Kenora Dist...... } 1 \\
\text { Walkingshaw L. }(25 \text { miles } \\
\text { N. Port Arthur)......... } 1 \\
\text { Whitney ................. } 1\end{array}$ & $\begin{array}{l}\text { Jan. } \\
\text { Feb. } \\
\text { Mar. } \\
\text { Apr. } \\
\text { May } \\
\text { June } \\
\text { July } \\
\text { Aug. } \\
\text { Sept. } \\
\text { Oct. } \\
\text { Nov. } \\
\text { Dec. }\end{array}$ & $\begin{array}{l}0 \\
1 \\
1 \\
1 \\
0 \\
0 \\
0 \\
0 \\
0 \\
0 \\
0 \\
3\end{array}$ \\
\hline
\end{tabular}

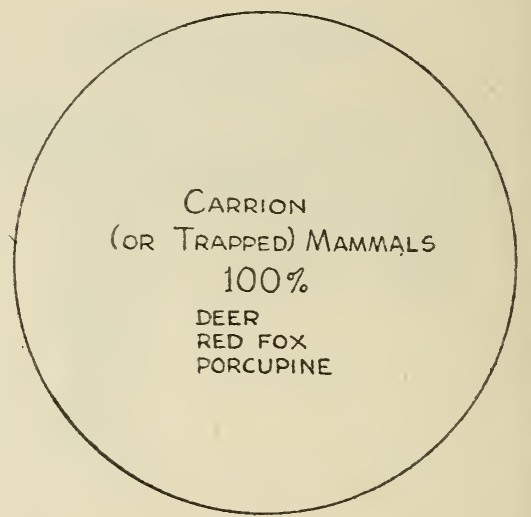

Although stomach content analyses seldom reveal whether the foods eaten were carrion or "kill," and it is known from other studies that this species will capture its own fare, circumstantial evidence leads to the interpretation that is shown in the graph. 


\section{BALD EAGLE}

Although this species is widely distributed throughout the province in summer, it has become so scarce as to make the sight of it an unusual experience. Adults may be distinguished on the wing by their large size and dark brown

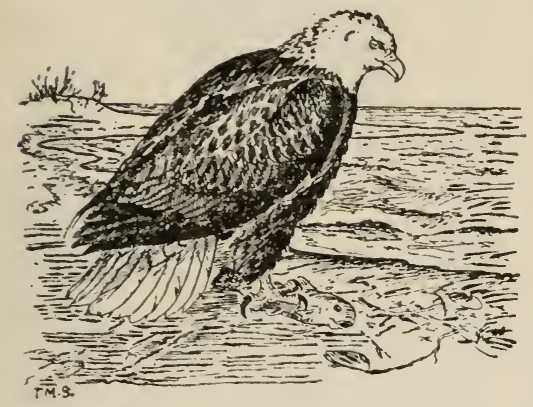
colour with white head and tail. Immatures resemble the golden eagle although their general brown colour is more broken by irregular light markings. The legs of the bald eagle are not feathered to the toes. The species was formerly to be expected about the many large bodies of water in the province - the Great Lakes and the larger lakes of the north-but there is now only an occasional pair left in the more remote places or where protection is afforded them. In winter these eagles are forced to move to situations where water remains open. They consequently appear not infrequently in the settled parts of the province in the fall and winter.

ORIGIN OF 6 STOMACHS EXAMINED OF WHICH 2 WERE EMPTY

\begin{tabular}{|c|c|c|}
\hline Locality & Mth. & No. \\
\hline 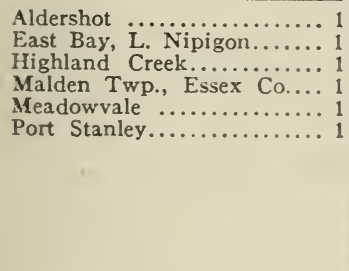 & $\begin{array}{l}\text { Jan. } \\
\text { Ieb. } \\
\text { Mar. } \\
\text { Apr. } \\
\text { May } \\
\text { June } \\
\text { July } \\
\text { Aug. } \\
\text { Scpt. } \\
\text { Oct. } \\
\text { Nov. } \\
\text { Dec. }\end{array}$ & $\begin{array}{l}0 \\
0 \\
0 \\
0 \\
0 \\
0 \\
1 \\
0 \\
1 \\
0 \\
2 \\
2\end{array}$ \\
\hline
\end{tabular}

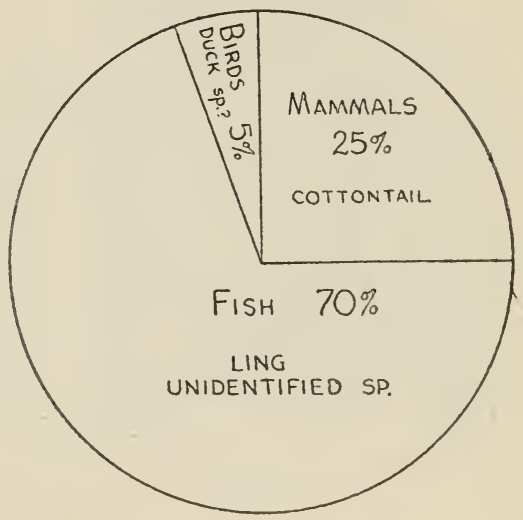

Studies made elsewhere and field observations lead to the interpretation that the food animals of all classes shown in the graph were carrion, or cripples. 


\section{MARSH HAWK}

Length-approx. 19 inches

Spread-approx. 45 inches

This is one of our commonest hawks. It nests about marshy areas in the south and open muskegs in the north.

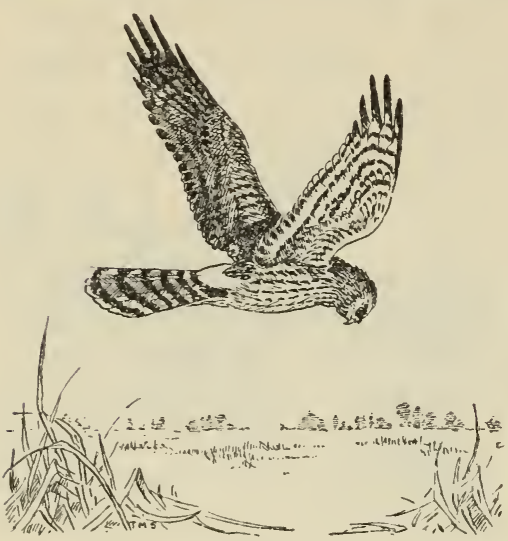

Its long tail and pointed wings together with its white rump are diagnostic. The light blue-gray back and black wing-tips of adult males give them a gull-like appearance on the wing. Adult females are brown above; their underparts buff, streaked with brown. Immatures resemble adult females but are less streaked and richer brown below. This hawk has a slight development of a facial disc similar to that of owls. In hunting, marsh hawks fly fairly close to the ground, coursing back and forth over marsh or muskeg or along meadow creeks and grassy fields. Now and then they hover, perhaps drop out of sight in the grass, to rise again and flap onward, swaying this way and that, ever on the lookout below. Occasionally individuals winter in southern Ontario.

ORIGIN OF 27 STOMACHS EXAMINED OF WHICH 2 WERE EMPTY

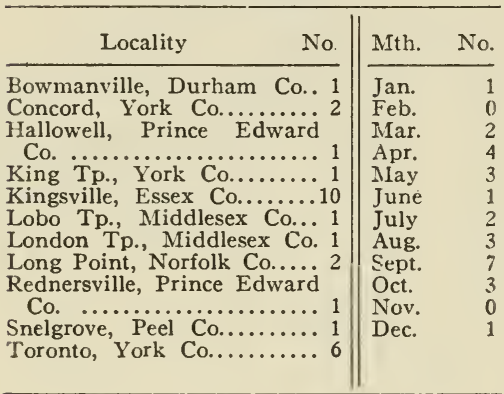

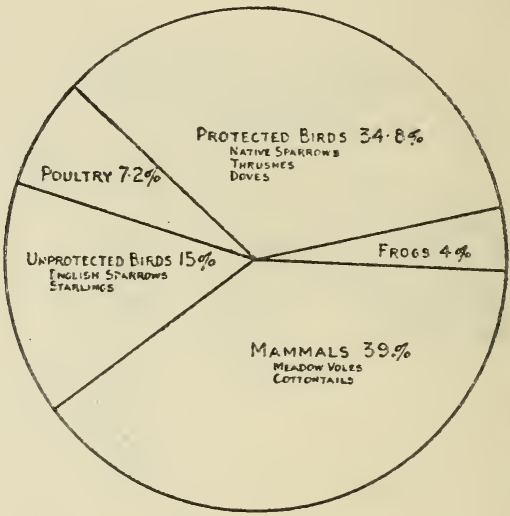

The material on which the above graph is based represents ten months of the year, but geographically it concerns only southern Ontario. Poultry forms an appreciable percentage of the marsh hawk's diet. It may therefore be necessary to guard against this species under circumstances such as about poultry farms. 


\section{OSPREY}

This large "fish hawk" occurs sparingly over most of the province, more particularly about the lake country of the

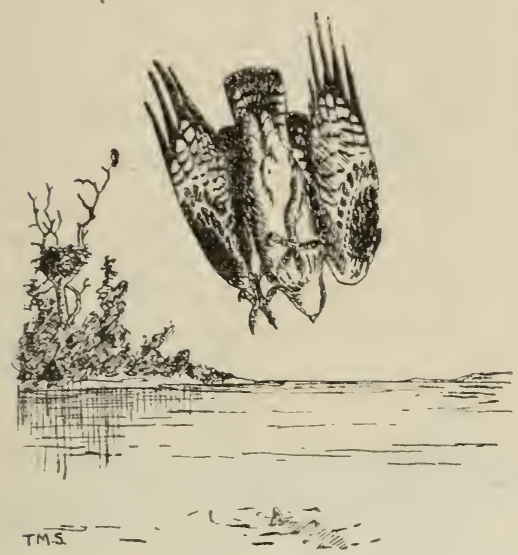
north. It is rare in southern Ontario except on migration, although it formerly occupied the shores of the lower Great Lakes. Its magnificent wingspread gives it an especially picturesque appearance and often leads to its being mistaken for an eagle. Ospreys are largely dark brown above and white below with an inconspicuous belt of brown spots across the breast. A large amount of white on the head is usually visible at a distance. The species hunts at a considerable elevation over the shallow waters of bays and lakes. After hovering to locate its elusive quarry, it dives through the air and into the water, feet extended forward at the last instant. When our northern lakes freeze over the osprey is forced to migrate southward.

\begin{tabular}{|c|c|c|}
\hline Locality & Mth. & No. \\
\hline 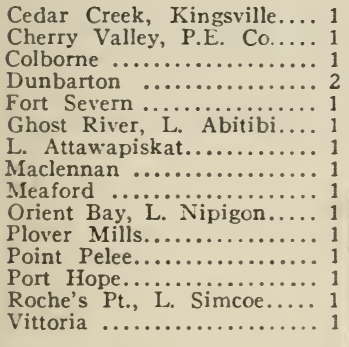 & $\begin{array}{l}\text { Jan. } \\
\text { Feb. } \\
\text { Mar. } \\
\text { Apr. } \\
\text { May } \\
\text { June } \\
\text { July } \\
\text { Aug. } \\
\text { Sept. } \\
\text { Oct. } \\
\text { Nov. } \\
\text { Dec. }\end{array}$ & $\begin{array}{l}0 \\
0 \\
0 \\
0 \\
2 \\
2 \\
3 \\
0 \\
8 \\
1 \\
0 \\
0\end{array}$ \\
\hline
\end{tabular}

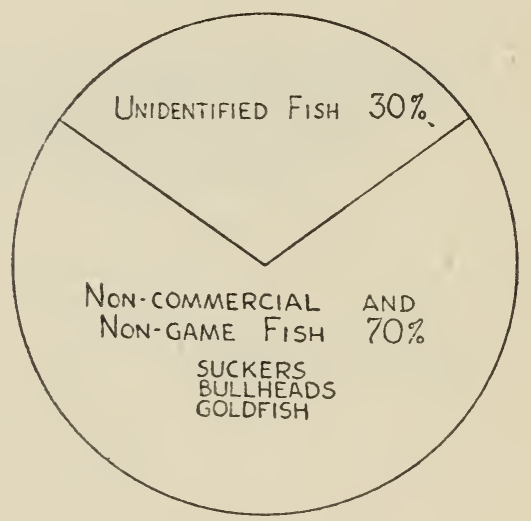

The few specimens whose stomach content examinations are represented by the above graph are insufficient to give an adequate idea of the variety of fish eaten by the osprey but they indicate that the kinds taken are largely those of little or no direct value to man. 


\section{CARACARA}

Length-approx. 22 inches

Spread-approx. 48 inches

This species is normally of southern distribution, occurring in tropical and subtropical regions of North America. It is included among the hawks of Ontario on the basis of a

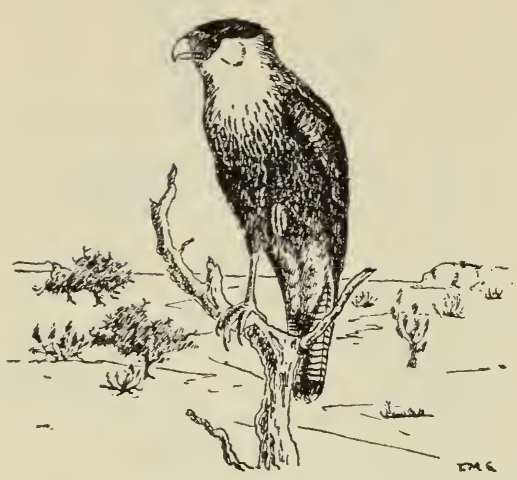
single record which was considered as the accidental occurrence of a storm-blown individual. Adults are blackbodied birds with white necks graded into the body colour by dark barring. Their tails are white with numerous dusky bars, the terminal one being broad. Immatures have the black areas replaced by brown, the breast and neck streaked, not barred. On the wing this species is said to be curiously stiff and angular in its appearance due to its long wings and contrasting colour pattern. It is the national bird of Mexico. The opportunity of seeing it in Ontario is highly improbable.

\footnotetext{
THE FOOD OF THIS SPECIES IS LARGELY CARRION, ALTHOUGH IT ALSO TAKES LIVE

MAMMALS, FISH AND REPTILES ACCORDING TO STUDIES

MADE ELSEWHERE
}

No stomachs examined. 


\section{GYRFALCON}

This beautiful bird is a resident of the treeless Arctic, seldom venturing into settled sections. It is only of very casual occurrence in southern Ontario, in fall and winter. Various colour phases are recognized, one being largely white, with some dark crossspotting above and a slight spotting below. Another is a dark, slaty phase and individuals exhibit intermediate plumages. Like all falcons, it has strong, pointed wings and is capable of swift, dashing flight. In its Arctic home it frequents the barren, rocky cliffs on the sea. Little can be said of it as regards the territory of Ontario except that it is probably not infrequent in occurrence in the extreme north in winter. An observer in settled parts of the province will indeed be fortunate if he ever observes the species.

THE FOOD OF THIS SPECIES IS LARGELY BIRDS AND MAMMALS WHICH FREQUENT THE VICINITY OF ITS ARCTIC HABITAT ACCORDING TO STUDIES MADE ELSEWHERE

No stomachs examined. 


\section{PEREGRINE FALCON}

Only an occasional pair of peregrine falcons is to be found throughout the extent of our province. The characteristic

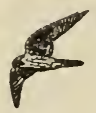

habitat of this species is about isolated cliffs high up over the shores of lakes, or on prominences dominating

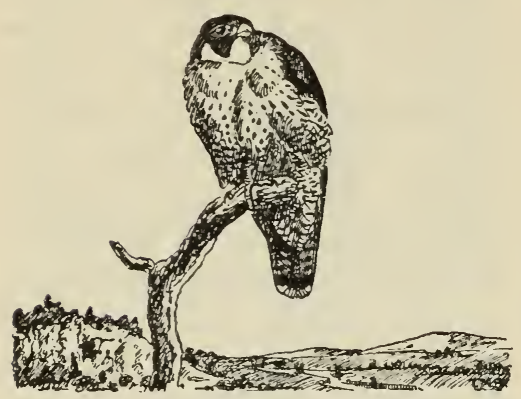
some flat valley. Fully adult birds have a black cap and "moustache," and are bluishgrey above and whitish or pinkish buff marked with dark brown below, except on the throat and upper breast. Immature birds are similar, although somewhat browner above, while below they are light buff heavily streaked with brown. The flight of this hawk is considered to be one of the most remarkable demonstrations of speed and manoeuvering among birds. It usually sights its prey while proceeding at high speed and folding its relatively long, pointed wings fairly close to its body, it drops upon its quarry like a meteor. The species migrates south in winter, usually frequenting lake shores en route.

ORIGIN OF 9 STOMACHS EXAMINED OF WHICH 2 WERE EMPTY

\begin{tabular}{|c|c|c|}
\hline Locality & Mth. & No. \\
\hline $\begin{array}{l}\text { Canboro ................. } 1 \\
\text { Jarvis Bluffs, James Bay.. } 4 \\
\text { Point Pelee................. } 2 \\
\text { Redwing ............. } 1 \\
\text { Ship Sands Is., James Bay. } 1\end{array}$ & $\begin{array}{l}\text { Jan. } \\
\text { Feb. } \\
\text { Mar. } \\
\text { Apr. } \\
\text { May } \\
\text { June } \\
\text { July } \\
\text { Aug. } \\
\text { Sept. } \\
\text { Oct. } \\
\text { Nov. } \\
\text { Dec. }\end{array}$ & $\begin{array}{l}0 \\
0 \\
0 \\
0 \\
1 \\
0 \\
0 \\
0 \\
1 \\
7 \\
0 \\
0\end{array}$ \\
\hline
\end{tabular}

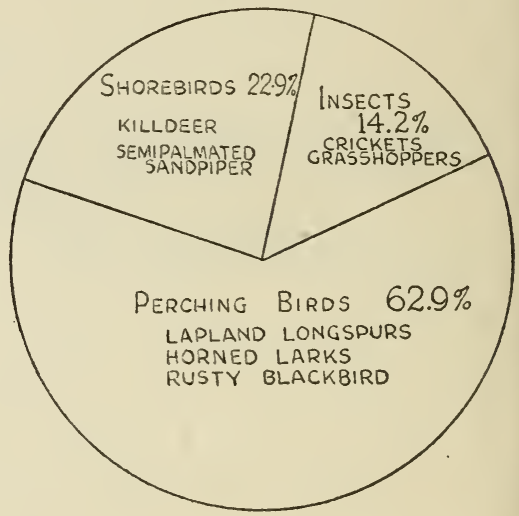

Although the number of stomachs examined is insufficient to show much of the range of diet of this rare falcon, it is evident that it is essentially a bird eater, taking the kinds available in wild, open country. 


\section{PIGEON HAWK}

Length-approx. 11 inches

Spread-approx. 25 inches

With the exception of the sparrow hawk, this is the most common of our falcons. It occurs sparingly throughout the northern forests in summer and appears as a migrant in southern Ontario, particularly along lake shores in spring and fall. It has the sturdy build and pointed wings characteristic of falcons and in size can only be confused with the sparrow hawk. Its manner and colour, however, are distinctive. Adult males are dark, slaty blue above and tawny below streaked with brown except on the throat which is white. Their tails are dark, barred with a light gray. Immatures and females are similar to males except that they are notably darker above. The weight of this falcon is not sufficient to give it the impetus for bullet-like swoops but it is a swift and dashing flyer, appearing somewhat like a pigeon in flight.

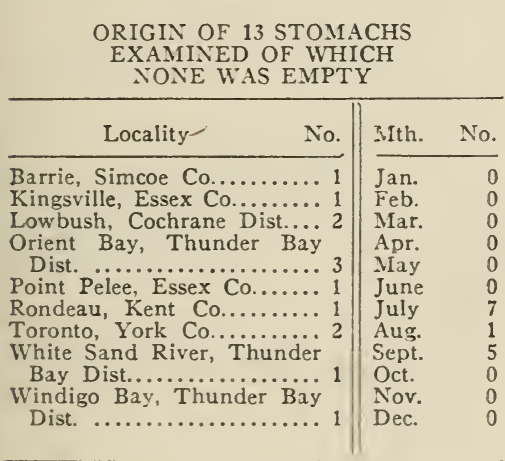

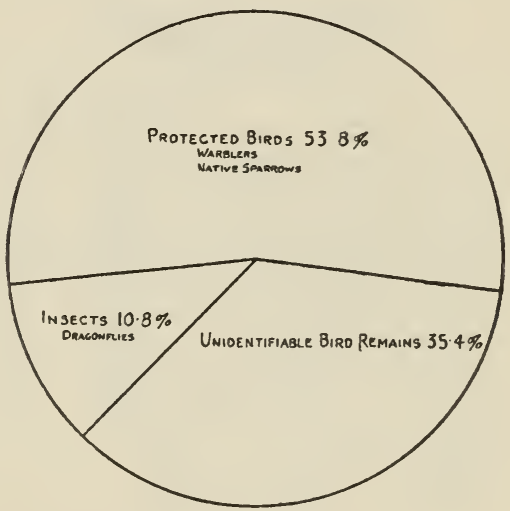

The above graph is based on the examination of specimens from their northern nesting grounds as well as of some taken on migration through southern Ontario, but from no section or season was an adequate number of specimens available for study. The results, however, indicate that though the food of the pigeon hawk consists of an appreciable proportion of insects, birds make up the greater part of it. 


\section{SPARROW HAWK}

Length-approx. 10 inches

Spread-approx. 22 inches

This little hawk inhabits wooded plots of southern, settled Ontario as well as the forests of the north. Males are strikingly coloured, with bluish

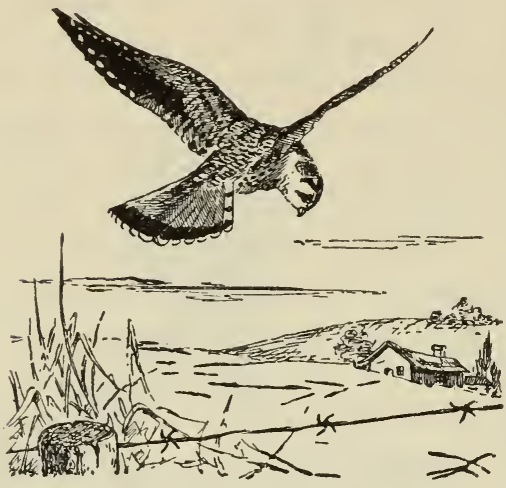
wings and rufous-brown backs marked with spots or barrings of darker colour. Below they are whitish or tawny more or less dotted with black. Their tails are rufous, broadly banded at the end with black and tipped with white. Females are rufous brown above, barred with dark markings on the back and tail; below they are buffy, streaked with light brown. When perching, this hawk frequently moves its tail up and down irregularly as though balancing. It is a master of hovering flight and can poise on beating wings over a likely spot in meadow or clearing, or, if the wind is right, can remain fixed in the air on set, outstretched wings for half a minute or more. A few individuals sometimes winter in southern Ontario.

ORIGIN OF 27 STOMACHS EXAMINED OF WHICH 3 WERE EMPTY

\begin{tabular}{|c|c|c|}
\hline Locality & Mth. & No. \\
\hline 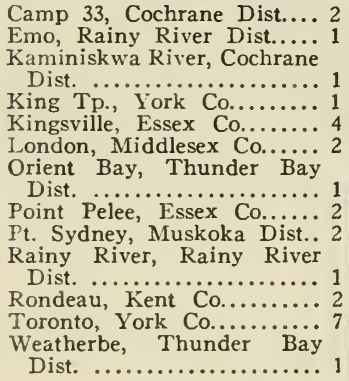 & $\begin{array}{l}\text { Jan. } \\
\text { Feb. } \\
\text { Mar. } \\
\text { Apr. } \\
\text { May } \\
\text { June } \\
\text { Jilly } \\
\text { Aug. } \\
\text { Sept. } \\
\text { Oct. } \\
\text { Nov. } \\
\text { Dec. }\end{array}$ & $\begin{array}{l}1 \\
0 \\
0 \\
5 \\
0 \\
4 \\
3 \\
3 \\
9 \\
2 \\
0 \\
0\end{array}$ \\
\hline
\end{tabular}

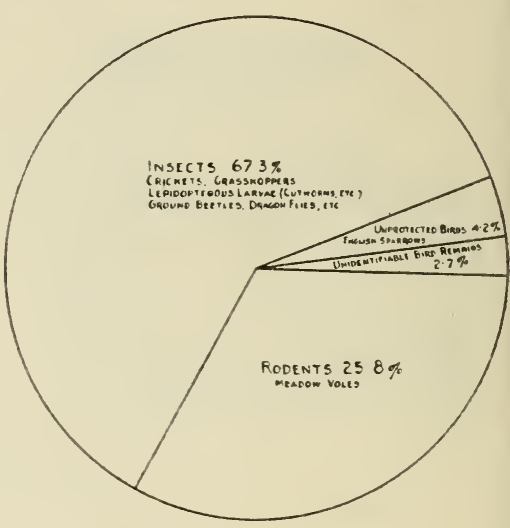

The proportion and variety of food items in the above graph are probably fairly representative of the average diet of the sparrow hawk during its residence in Ontario, and demonstrate how inappropriate is its common name. The specimens were from widely separated sections north and south including both settled and unsettled areas. 


\section{BARN OWL}

The barn owl, a southern species, is occasionally noted in settled Ontario, more particularly in the southern counties.

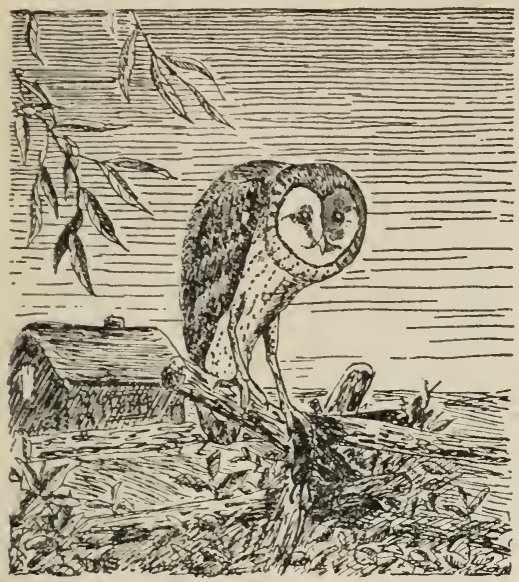

Its upper parts are mixed grey and yellow buff finely dotted with black and white and the underparts vary from white to buff, marked with small black dots. The dark eyes are set in a white, heartshaped, facial disc producing the curious visage of this owl which is unique among our birds. Its legs are long and it does not possess ear-tufts. The capture of a specimen is usually reported in local press accounts in terms which suggest that some freak or hybrid between an owl and a monkey had been discovered. This has given rise to the name "monkey-faced owl" in some localities. The species frequents wooded areas as well as situations about buildings. Like most owls, it hunts at night. It appears to be migratory in the northern part of its range.

THE FOOD OF THIS OWL IS PRINCIPALLY MICE, ACCORDING TO STUDIES MADE ELSEWHERE

Fewer than six stomachs examined. 


\section{SCREECH OWL}

Length-approx. 9 inches

Spread-approx. 22 inches

The screech owl is perhaps our best known species. It occurs throughout the southern, settled portions of Ontario,

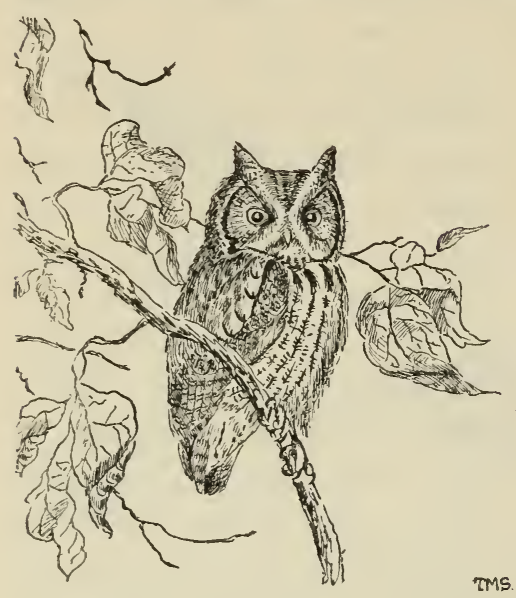

but not in the forested sections of the north: Two colour phases occur, individuals being either grey or rufous, the latter being the least common. Specimens intermediate in colour are rare. The pattern is similar in both phases, the back feathers being finely streaked with black, and there are some more or less concealed white markings. Below, the feathers are streaked with black, the grey phase being also more or less barred with black. "Ear-tufts" are present and the eyes are yellow. The tremulous call of this owl is familiar to persons in the city as well as in rural districts since the species frequents the shade trees of residential streets as well as farm orchards, groves and woods. This owl is nocturnal and non-migratory.

\begin{tabular}{|c|c|c|}
\hline Locality & Mth. & No. \\
\hline $\begin{array}{l}\text { King Tp., York Co........ } 1 \\
\text { Kingsville, Essex Co........ } 4 \\
\text { Lobo Tp., Middlesex Co... } 8 \\
\text { London Tp., Middlesex Co. } 4 \\
\text { Plover Mills, Middlesex Co. } 1 \\
\text { Pottageville, York Co...... } 1 \\
\text { Toronto, York Co........ } 7 \\
\text { Vineland, Lincoln Co...... } \\
\text { Woodville, Victoria Co...... } 1\end{array}$ & $\begin{array}{l}\text { Jan. } \\
\text { Feb. } \\
\text { Mar. } \\
\text { Apr. } \\
\text { May } \\
\text { June } \\
\text { July } \\
\text { Aug. } \\
\text { Sept. } \\
\text { Oct. } \\
\text { Nov. } \\
\text { Dec. }\end{array}$ & $\begin{array}{l}5 \\
7 \\
0 \\
1 \\
0 \\
5 \\
0 \\
0 \\
1 \\
5 \\
4 \\
1\end{array}$ \\
\hline
\end{tabular}

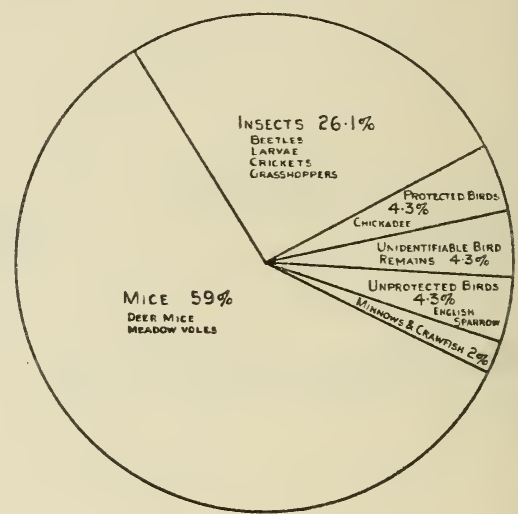

The above graph is based on the examination of specimens from various points in the normal range of the screech owl in Ontario and the number represented is probably sufficient to indicate fairly accurately the average food habits of the species. Items other than mice and insects are taken in small proportions. 


\section{HORNED OWL*}

Length-approx. 23 inches

Spread-approx. 56 inches

This owl inhabits heavily wooded areas throughout the province, although in the south it is confined more particularly

to swampy woods. It is not

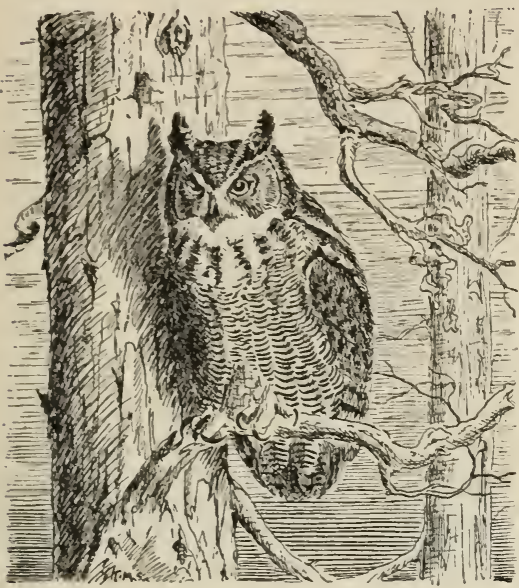

uncommon in Ontario as a whole. In colour the species is greatly variable, some individuals showing a predominance of white, others being more or less sooty black. The resident form in more southern sections is mottled dark buff and black above, and below it is buff barred with black, interspersed with some white markings, the throat area being white. The species has prominent black ear-tufts and its eyes are yellow. The nocturnal habits, the large size and the loud, unbird-like voice of this species seem to be the combination of characters which caused weird attributes to be popularly bestowed on owls. One of its calls, a "whoo, hoo-hoo, whooo, whooo," is characteristic. The species wanders in the fall.

\begin{tabular}{|c|c|c|}
\hline Locality & Mth. & No. \\
\hline 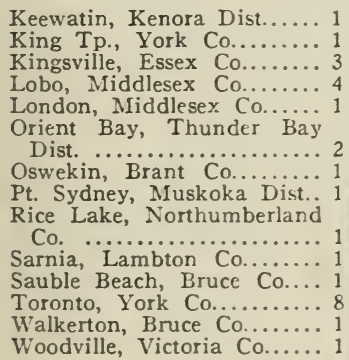 & $\begin{array}{l}\text { Jan. } \\
\text { Feb. } \\
\text { Mar. } \\
\text { Apr. } \\
\text { May } \\
\text { June } \\
\text { July } \\
\text { Aug. } \\
\text { Sent. } \\
\text { Oct. } \\
\text { Nov. } \\
\text { Dec. }\end{array}$ & $\begin{array}{l}3 \\
4 \\
3 \\
0 \\
2 \\
4 \\
0 \\
0 \\
2 \\
1 \\
4 \\
4\end{array}$ \\
\hline
\end{tabular}

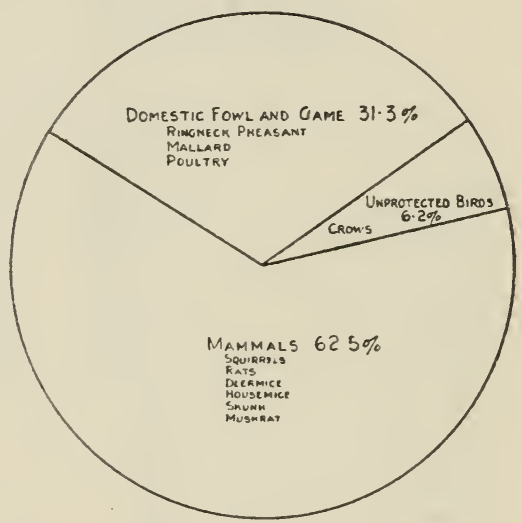

The material for studying the food of the great horned owl was secured from widely distributed sections of the province and concerns all seasons of the year except midsummer. The picture presented by the graph is therefore fairly representative of the average food habits of the species. It is evident that it is necessary to guard against this owl in cultivated districts.

*Including three races occurring in Ontario. 


\section{SNOWY OWL}

This inhabitant of the barren grounds of the Arctic invades southern Ontario periodically in the fall, sometimes in considerable numbers. Adult males are predominately white with some small brown

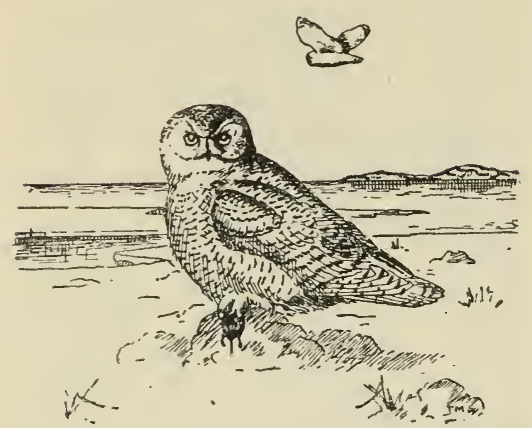
markings. Females are more heavily marked with brown, as are also immatures. No conspicuous ear tufts are present, and their eyes are yellow. Its diurnal habits, together with its large size, render it rather conspicuous during its visits to settled sections. During its periodic residence in southern latitudes, it frequents marshy areas, lake shores and cultivated lands. The fairly rapid flight of this owl is accomplished by a rather slow, firm flapping somewhat gull-like and is frequently punctuated by short sails. It usually perches on the ground or on objects near the ground.

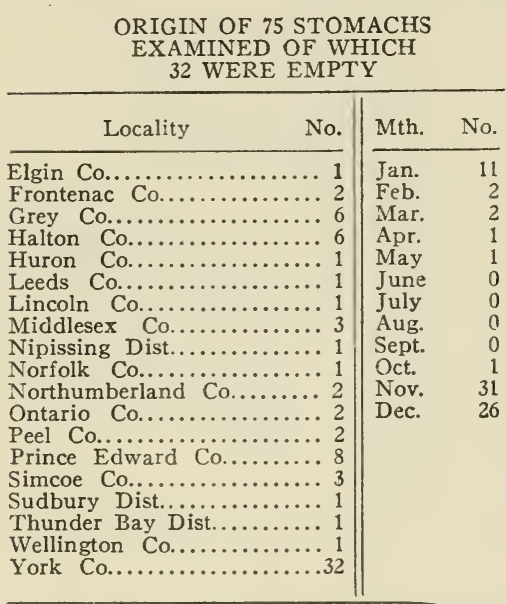

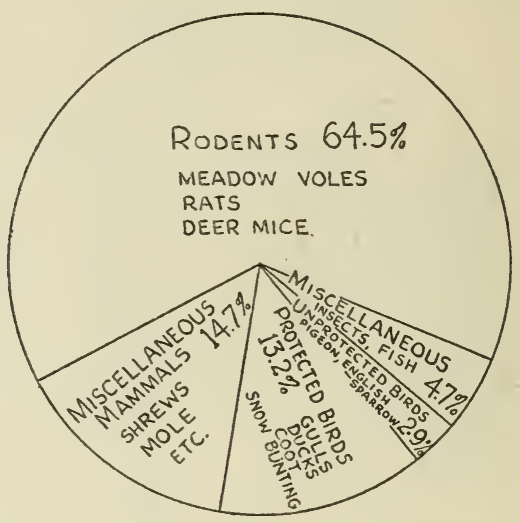

The fish item shown in the graph under miscellaneous foods was the head of a large lake trout, obviously carrion. It is highly probable that some of the protected birds shown in the graph were also carrion found along beaches. 


\section{HAWK OWL}

This owl is a resident of the far northern forests; in fall and winter it sometimes, though rarely, is found in settled sections farther south. The species does not possess ear-tufts.

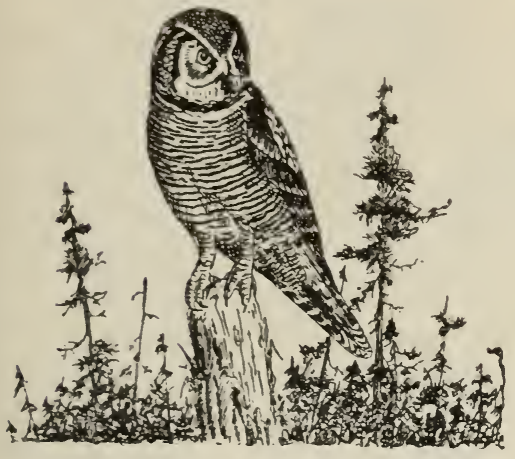
Its eyes are yellow and the grayish facial disc is bordered by a black outline. Adults are dark grey-brown above, marked with white on the head, neck and wings; their underparts a re whitish, barred with brown. Their tails are relatively long and rounded. Juveniles are similar to adults but possess a heavy brown belt across the upper breast, and below they are tawny, barred with brown. This owl is active during the day. While on the wing during hunting cruises, it has the appearance of a hawk. It frequently perches on dead stubs and in such positions it sometimes holds its long tail erect, at a right angle to the body.

ORIGIN OF 14 STOMACHS

EXAMINED OF WHICH 2 WERE EMPTY

\begin{tabular}{|c|c|c|}
\hline Locality & Mth. & No. \\
\hline $\begin{array}{l}\text { Camp " } 33 \text { " Cochrane Dist.. } 1 \\
\text { Ghost River, Cochrane Dist. } 6 \\
\text { Little Current, Manitoulin } \\
\text { Dist. .................. 1 } \\
\text { Lowbush, Cochrane Dist.... } 1 \\
\text { McGregor Bay, Manitoulin } \\
\text { Dist. .................... } 1 \\
\text { Parry Sound, Parry Sound } \\
\text { Dist. ................ } 1 \\
\text { Pt. Sydney, Muskoka Dist.. } 1 \\
\text { Scotia Junc., Parry Sound } \\
\text { Dist. ................. 1 } \\
\text { Whitney, Nipissing Dist.... 1 }\end{array}$ & $\begin{array}{l}\text { Jan. } \\
\text { Feb. } \\
\text { Mar. } \\
\text { Apr. } \\
\text { May } \\
\text { June } \\
\text { July } \\
\text { Aug. } \\
\text { Sept. } \\
\text { Oct. } \\
\text { Nov. } \\
\text { Dec. }\end{array}$ & $\begin{array}{l}0 \\
0 \\
0 \\
0 \\
0 \\
7 \\
1 \\
0 \\
0 \\
0 \\
3 \\
3\end{array}$ \\
\hline
\end{tabular}

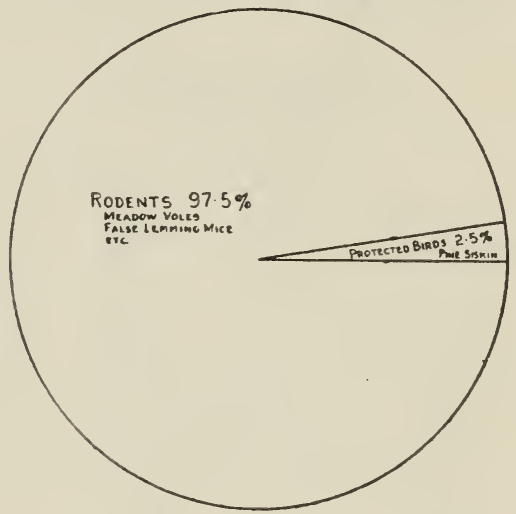

The food of the hawk owl in summer and in winter as suggested by the limited number of stomachs examined consists of such a high percentage of small rodents that it seems unlikely that further material would greatly alter the picture presented in the above graph. The districts represented in the accompanying table of specimens are in the north, the normal range of this owl. 


\section{BARRED OWL}

This owl is principally of southern distribution although it occurs northward to the borders of the eastern coniferous

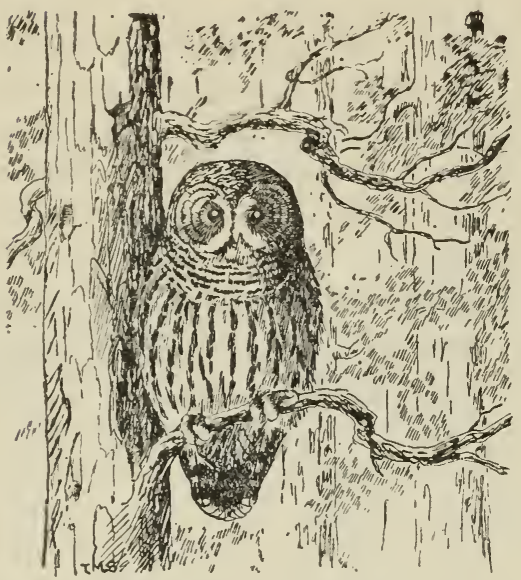
forest, even in the districts west of Lake Superior. Though still not common, the barred owl has increased somewhat in recent years. The species has no ear-tufts, the bill is yellow, the eyes are dark brown and the facial disc is grey, finely barred with a darker tone. Above it is greyish brown, barred with whitish; the grey underparts are conspicuously marked with brown, barred on the chest and streaked below. The call of this owl has given rise to the name "hoot-owl." There is a considerable variation in its "whoo-whoo-whoo, whoo-whoo, who-who-oah" call, but the descending final syllable, "whoo-ah," is characteristic. It is a woodland species, nocturnal in habits and not strictly migratory although somewhat of a wanderer.

ORIGIN OF 31 STOMACHS

EXAMINED OF WHICH 4 WERE EMPTY

\begin{tabular}{|c|c|c|}
\hline Locality & Mth. & No. \\
\hline 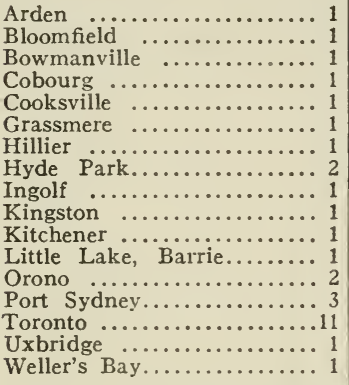 & $\begin{array}{l}\text { Jan. } \\
\text { Feb. } \\
\text { Mar. } \\
\text { Apr. } \\
\text { May } \\
\text { June } \\
\text { July } \\
\text { Aug. } \\
\text { Sept. } \\
\text { Oct. } \\
\text { Nov. } \\
\text { Dec. }\end{array}$ & $\begin{array}{l}4 \\
4 \\
1 \\
0 \\
1 \\
1 \\
1 \\
0 \\
0 \\
6 \\
9 \\
4\end{array}$ \\
\hline
\end{tabular}

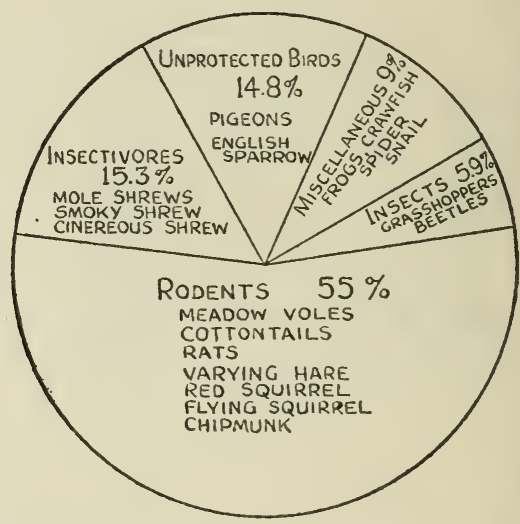

The distribution and number of sto machs exa mined are adequate to give a fair estimate of the variety and percentages of food animals eaten. 


\section{GREAT GRAY OWL}

Length-approx. 27 inches

Spread-approx. 60 inches

Although the great gray owl appears larger and measures longer than any other Ontario species, certain others exceed

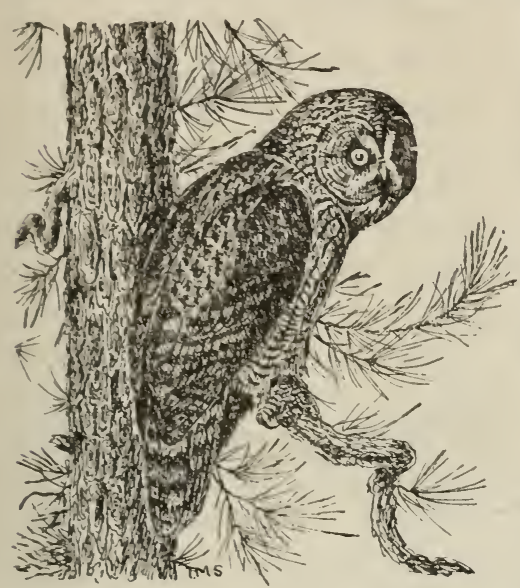

it in weight. It is a rare and little-known inhabitant of our northern evergreen forests, seldom wandering south to settled areas. In general appearance it most nearly resembles the barred owl. Like that species it does not possess ear-tufts, the bill is yellow and the general colour above is grey-brown mottled with whitish. But it is unlike the barred owl in possessing yellow eyes and the pattern of the underparts is reversed, being whitish with broad streaks on the breast and vaguely barred below with brown. The tail, which is relatively long, somewhat exaggerates the size of this owl. Fall and winter flights of the species into settled Ontario occur so seldom and so irregularly that it will rarely be observed in this area. It is, like most owls, nocturnal in habits.

ORIGIN OF 10 STOMACHS

EXAMINED OF WHICH NONE WAS EMPTY

\begin{tabular}{|c|c|c|}
\hline Locality & Mth. & No. \\
\hline 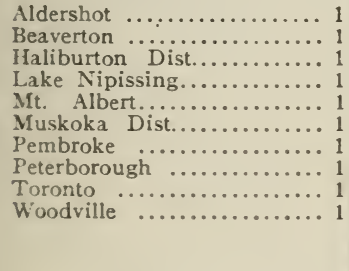 & $\begin{array}{l}\text { Jan. } \\
\text { Feb. } \\
\text { Mar. } \\
\text { Apr. } \\
\text { May } \\
\text { June } \\
\text { July } \\
\text { Aug. } \\
\text { Sept. } \\
\text { Oct. } \\
\text { Nov. } \\
\text { Dec. }\end{array}$ & $\begin{array}{l}2 \\
3 \\
0 \\
0 \\
0 \\
0 \\
0 \\
0 \\
0 \\
1 \\
1 \\
3\end{array}$ \\
\hline
\end{tabular}

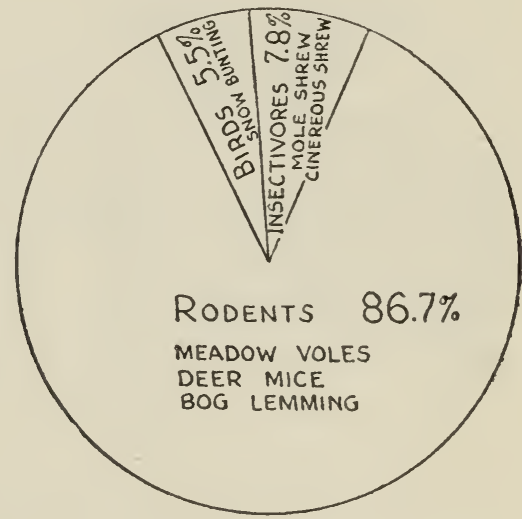

The spring and summer seasons are not represented in the material examined and too few specimens were secured, but the evidence presented in the above graph suggests that the great gray owl is primarily a mouser. The small size of the prey in relation to that of the owl is notable. 


\section{LONG-EARED OWL}

The long-eared owl is fairly common and widely distributed over the province, frequenting the more heavily wooded

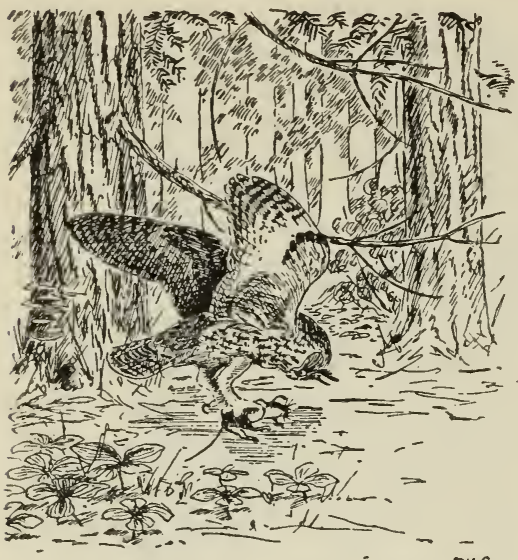
portions of the south as well as the forests of the north. Adults are brownish black above, mottled with white and buff; the underparts are whitish and buff, irregularly barred with dark brown. It possesses feather ear-tufts which are approximately one and one-half inches in length; its buffy facial disc is bordered with black. The eyes are yellow. Like most other owls it is active at night and consequently seldom seen, but if disturbed in the daytime it will fly with a slow, wavering, buoyant flight. Individuals wander in the fall at which season they appear in more scantily wooded situations, particularly those along the shores of Lakes Ontario and Erie.

ORIGIN OF 21 STOMACHS

EXAMINED OF WHICH 3 WERE EMPTY

\begin{tabular}{|c|c|c|}
\hline Locality & Mth. & No. \\
\hline 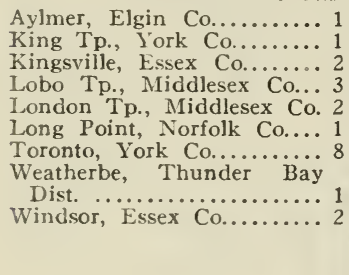 & $\begin{array}{l}\text { Jan. } \\
\text { Feb. } \\
\text { Mar. } \\
\text { Apr. } \\
\text { May } \\
\text { June } \\
\text { July } \\
\text { Aug. } \\
\text { Sept. } \\
\text { Oct. } \\
\text { Nov. } \\
\text { Dec. }\end{array}$ & $\begin{array}{l}2 \\
4 \\
1 \\
0 \\
1 \\
1 \\
0 \\
1 \\
0 \\
7 \\
2 \\
2\end{array}$ \\
\hline
\end{tabular}

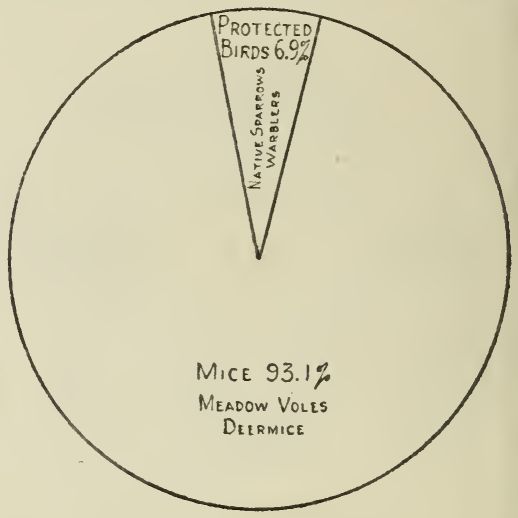

The number of stomach content examinations and the localities and seasons represented indicate very definitely that the long-eared owl is largely a mouse-eating species. Few of our widely distributed birds of prey are so specific in their diet. 


\section{SHORT-EARED OWL}

Length-approx. 16 inches

Spread-approx. 42 inches

This owl is not of general distribution in Ontario. It is fairly common in cleared land in western sections (Rainy River region) and is also to be found in open areas about
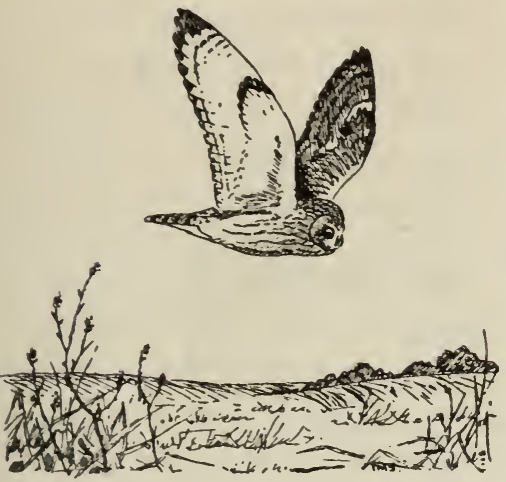

James Bay. In southern Ontario it is a rare summer resident of some marshes, but appears to be absent from the vast forested areas of the north. Adults are brownish above, the feathers bordered with cream or buff; the underparts vary from whitish to buffy, streaked with brown. Immatures are darker buff than adults. The eyes are yellow and the rather inconspicuous ear-tufts are centred on the forehead. The short-eared owl hunts by day, particularly in summer, and while on the wing the dark markings under the wings at the wrists are particularly conspicuous. Its flight is a rather slow, easy flapping, somewhat erratic, usually fairly close to the ground. The species migrates in the fall in loose bands; some winter in the southern sections.

\begin{tabular}{|c|c|c|}
\hline \multicolumn{3}{|c|}{$\begin{array}{c}\text { ORIGIN OF } 27 \text { STOMACHS } \\
\text { EXAMINED OF WHICH } \\
6 \text { WERE EMPTY }\end{array}$} \\
\hline Locality & Mth. & No. \\
\hline $\begin{array}{l}\text { Aylmer, Elgin Co.......... } 1 \\
\text { Emo, Rainy River Dist..... } \\
\text { Kingsville, Essex Co....... } 1 \\
\text { Lobo Tp., Middlesex Co... } \\
\text { Long Point, Norfolk Co... } \\
\text { Sarnia, Lambton Co....... } \\
\text { Toronto, York Co......... } 16 \\
\text { Tyrconnel, Elgin Co....... } 1\end{array}$ & $\begin{array}{l}\text { Jan. } \\
\text { Feb. } \\
\text { Mar. } \\
\text { Apr. } \\
\text { Miay } \\
\text { June } \\
\text { July } \\
\text { Aug. } \\
\text { Sept. } \\
\text { Cct. } \\
\text { Nov. } \\
\text { Dec. }\end{array}$ & $\begin{array}{r}1 \\
0 \\
0 \\
1 \\
0 \\
3 \\
2 \\
1 \\
0 \\
16 \\
3 \\
0\end{array}$ \\
\hline
\end{tabular}

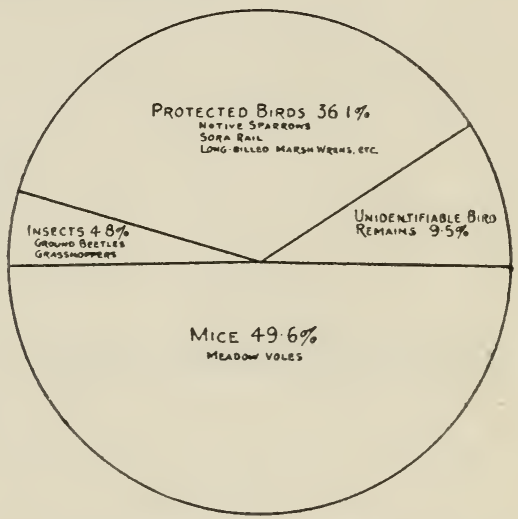

The above graph based on the examination of stomachs of specimens which were mostly taken in the fall shows that the short-eared owl feeds almost equally on small rodents and birds. Although studies of food habits based on regurgitated pellets have not been included in any graph in this booklet, a study of pellets of this species in the Toronto region indicates that availability is an important factor in the proportions of food items eaten. In winter, when most birds have migrated, mice constitute as high as $99 \%$ of the food of this owl. 


\section{TENGMALM'S OWL}

Length-approx. $10 \mathrm{i}$ nches Spread-approx. 24 inches

This rare little owl is seldom seen anywhere in Ontario. Occasionally it appears in southern sections in winter when

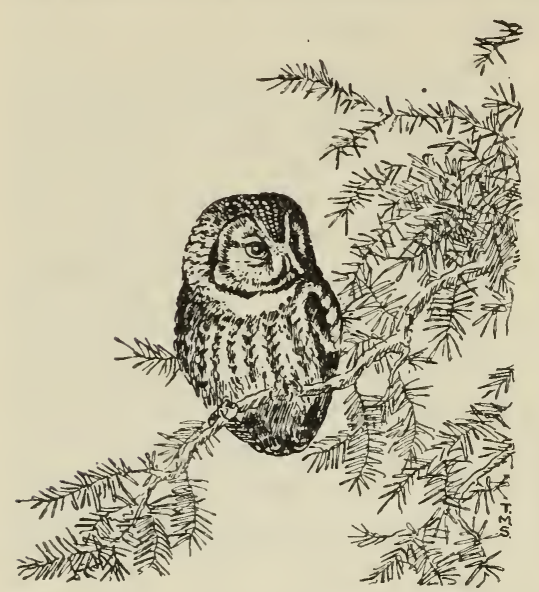
individuals wander southward from their summer range. The upper parts of adults are greyish brown spotted with white. Below they are white, heavily streaked with brown. Immatures are dark brown above, somewhat spotted with white and brown and tawny below. The species has yellow eyes. Tengmalm's owl resembles the saw-whet, except that it is spotted instead of streaked with white on the head, is slightly larger and the bill is yellowish not blackish. Although it is probably sparsely distributed throughout our northern forests it is seldom seen, mainly because it is not numerous, but also because of its small size and nocturnal habits.

THE FOOD OF THIS OWL IS CHIEFLY MICE AND OTHER SMALL MAMMALS, ACCORDING

TO STUDIES MADE ELSEWHERE

Fewer than six stomachs examined. 


\section{SAW-WHET OWL}

Length-approx. 8 inches

Spread-approx. 17 inches

This, the smallest owl in Ontario, is distributed, in summer, in wooded areas over most of the province but it is rarely

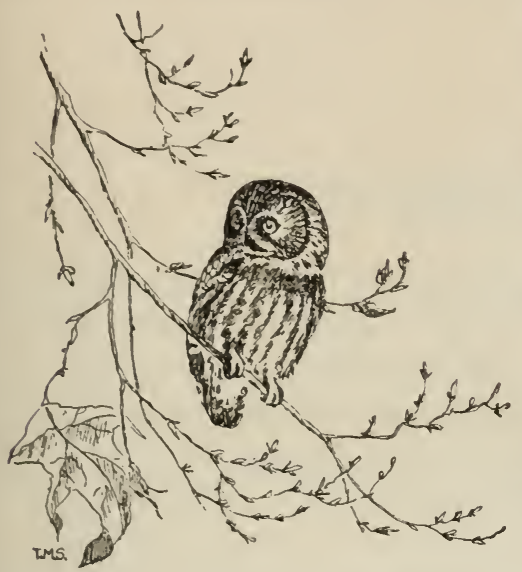
seen because of its small size, its nocturnal habits and because it is not particularly common. Adults are dark cinnamon brown above, spotted with white on the back and with white streaks on the head. The underparts are white, heavily streaked with brown, or yellowish brown. Their eyes are yellow. Immatures are brown above and on the breast, with little or no white, and tawny buff below.

This little owl is most like Tengmalm's owl, but the head is streaked, not spotted with white as in that species, and the bill is dark. Although the saw-whet is somewhat migratory it is not completely so, being more of a wanderer. It appears in greater or less numbers in winter along the shores of Lake Ontario and Lake Erie.

\begin{tabular}{|c|c|c|}
\hline Locality & Mth. & No. \\
\hline $\begin{array}{l}\text { Kingsville, Essex Co....... } 1 \\
\text { Lobo Tp., Middlesex Co... } \\
\text { Long Point, Norfolk Co.... } \\
\text { Pt. Sydney, Muskoka Dist.. } \\
\text { Toronto, York Co............ }\end{array}$ & $\begin{array}{l}\text { Jan. } \\
\text { Feb. } \\
\text { Mar. } \\
\text { Apr. } \\
\text { Mlay } \\
\text { June } \\
\text { July } \\
\text { Aug. } \\
\text { Sept. } \\
\text { Oct. } \\
\text { Nov. } \\
\text { Dec. }\end{array}$ & $\begin{array}{l}0 \\
5 \\
c \\
1 \\
5 \\
0 \\
1 \\
0 \\
0 \\
2 \\
1 \\
1\end{array}$ \\
\hline
\end{tabular}

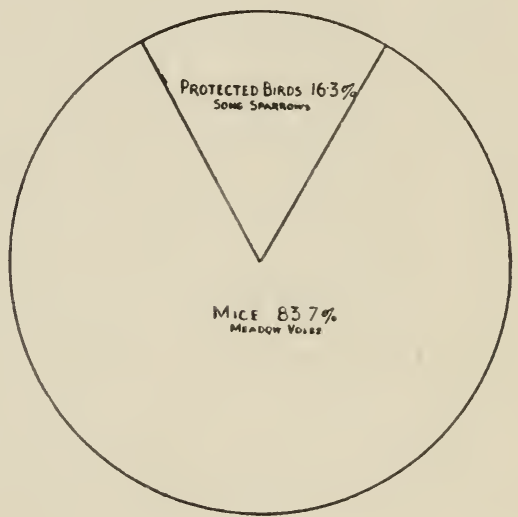

The localities from which the material examined was secured are not sufficiently numerous and well distributed to give a satisfactory account of the food habits of the saw-whet owl for the province as a whole. The average annual diet of the species in southern Ontario is, however, fairly conclusively shown by the above graph. 



\section{HANDBOOK SERIES}

[unnumbered], Guide to the Game Fishes of Canada, [by J. R.

Dymond]. 20 pages. 1927. (Out of print.)

No. 1, The Mammals of Ontario, by E. C. Cross and J. R. Dymond, 55 pages. 1929. (Out of print.)

No. 2, The Hawks and Owls of Ontario, by L. L. Snyder. Pen and ink drawings by T. M. Shortt. 48 pages. 1932. Revised edition.

No. 3, The Amphibians of Ontario, by E. B. S. Logier. Pen and ink drawings by the author. 16 pages. 1937.

No. 4, The Reptiles of Ontario, by E. B. S. Logier. Pen and ink drawings by the author. 81 pages. 1939 . 




(1)

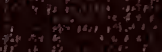

(ain

and

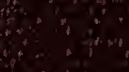

$+2 \sin 2$

$\cos ^{2}+\cdots$

a

(15)

40

5 (n)

What, in

4 (a) 